\title{
Early diagenetic dolomitization and dedolomitization of Late Jurassic and earliest Cretaceous platform carbonates: A case study from the Jura Mountains (NW Switzerland, E France)
}

\author{
Niels Rameil* \\ Université de Fribourg, Faculté de Géosciences - Géologie et Paléontologie, Ch. du Musée 6, CH-1700 Fribourg, Switzerland
}

\begin{abstract}
Early diagenetic dolomitization is a common feature in cyclic shallow-water carbonates throughout the geologic record. After their generation, dolomites may be subject to dedolomitization (re-calcification of dolomites), e.g. by contact with meteoric water during emersion. These patterns of dolomitization and subsequent dedolomitization frequently play a key role in unravelling the development and history of a carbonate platform. On the basis of excellent outcrops, detailed logging and sampling and integrating sedimentological work, high-resolution sequence stratigraphic interpretations, and isotope analyses $(\mathrm{O}, \mathrm{C})$, conceptual models on early diagenetic dolomitization and dedolomitization and their underlying mechanisms were developed for the Upper Jurassic / Lower Cretaceous Jura platform in north-western Switzerland and eastern France. Three different types of early diagenetic dolomites and two types of dedolomites were observed. Each is defined by a distinct petrographic/isotopic signature and a distinct spatial distribution pattern. Different types of dolomites are interpreted to have been formed by different mechanisms, such as shallow seepage reflux, evaporation on tidal flats, and microbially mediated selective dolomitization of burrows. Depending on the type of dolomite, sea water with normal marine to slightly enhanced salinities is proposed as dolomitizing fluid. Based on the data obtained, the main volume of dolomite was precipitated by a reflux mechanism that was switched on and off by high-frequency sea-level changes. It appears, however, that more than one dolomitization mechanism was active (pene)contemporaneously or several processes alternated in time. During early diagenesis, percolating meteoric waters obviously played an important role in the dedolomitization of carbonate rocks that underlie exposure surfaces. Cyclostratigraphic interpretation of the sedimentary succession allows for estimates on the timing of early diagenetic (de)dolomitization. These results are an important step towards a better understanding of the link between high-frequency, probably orbitally forced, sea-level oscillations and early dolomitization under Mesozoic greenhouse conditions.
\end{abstract}

\section{Introduction}

Dolomite-capped cycles are common features in shallow-water carbonates and have been reported throughout the geologic record (Goldhammer et al., 1990; Montañez and Read, 1992; Yoo and Lee, 1998; Bosence et al., 2000; Dehler et al., 2001). Their patterns, processes, and timing frequently play a key role in understanding the development of carbonate platforms. Moreover, the usually stratiform dolomite bodies may have economic implications when forming layercake hydrocarbon reservoirs (Swart et al., 2005; Borkhataria et al.,

\footnotetext{
* Corresponding author. Present address: Ruhr-Universität Bochum, Institut für Geologie, Mineralogie und Geophysik, Sediment- und Isotopengeologie, D-44780 Bochum, Germany. Fax: +49 2343214571

E-mail address: niels.rameil@rub.de.
}

2006). At a later stage, dedolomitization (calcitization of dolomites) may happen. One possible mechanism for dedolomitization, that is further explored in this paper, is by contact with percolating meteoric waters during subaerial exposure (Cantrell et al., 2007; Nader et al., 2008).

The goal of this study is to further the understanding of the links that exist between dolomitization and dedolomitization patterns, vertical facies distribution/cyclicity, the architecture of depositional sequences, and high-frequency oscillations of relative sea-level. Upper Kimmeridgian to Middle Berriasian carbonates of the Jura platform (NW Switzerland and E France) were recently subject of a detailed study, focussing on their sedimentology, sequence stratigraphy, and cyclostratigraphy (Rameil, 2005). On the basis of excellent outcrop conditions and detailed logging/sampling, conceptual models on dolomitization and dedolomitization patterns as well as their underlying mechanisms were developed for this example platform. Additionally, the application 


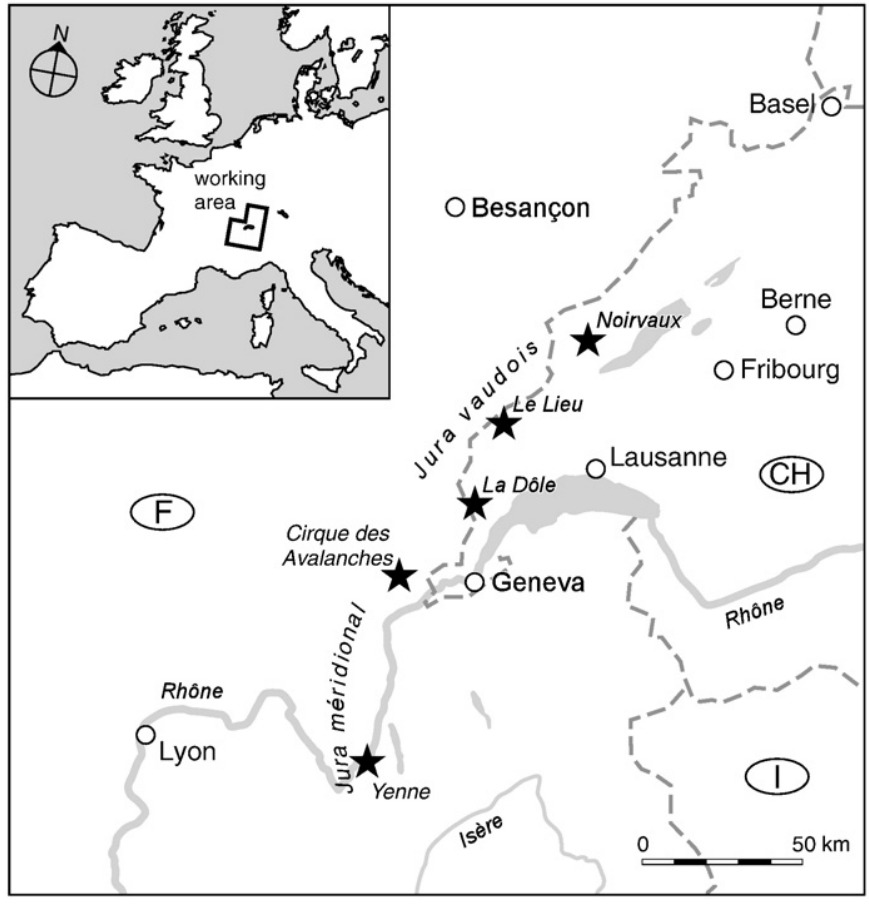

Fig. 1. Geographic overview of the working area with locations of measured sections.

of the proposed cyclostratigraphic timeframe (Rameil, 2005) allows for estimating the duration of the time interval during which early diagenetic processes were active.

\section{Geologic setting}

The study area is located in the central and southern Jura Mountains, the so-called Jura vaudois and Jura neuchâtelois of northwestern Switzerland and the Jura méridional of eastern France (Fig. 1). The Jura Mountains are a predominantly calcareous mountain chain of moderate height $(\sim 1700 \mathrm{~m})$ that trends subparallel to the northern Alpine Front. They mainly consist of the remains of a Jurassic and Lower Cretaceous carbonate platform that was folded and thrusted during the latest tectonic phases of the Alpine orogeny. Tectonic deformation, however, took place at rather shallow burial depth (thinskin tectonics) and resulted mainly in wide, open geometries of folds with only a minor thrusting component (e.g. Trümpy, 1980; Sommaruga, 1997). This leads to long, commonly steeply inclined, but relatively undisturbed sections that are accessible in natural gorges cutting into the folds normally to the fold axes and/or along road cuts. The study focuses on rocks of Late Kimmeridgian, Tithonian, and Early Berriasian age (Upper Reuchenette, Twannbach, and Goldberg Formations).

During the Late Jurassic and Early Cretaceous, central and western Europe consisted of a patchwork of low-relief islands in a shallow continental sea at the north-western passive margin of the Alpine Tethys. Here, the Jura platform represented the central part of the North-Tethyan platform. According to palaeogeographic reconstructions (e.g., Ziegler, 1990; Thierry, 2000), the palaeolatitude of the Jura platform was approximately $30^{\circ}$ to $35^{\circ} \mathrm{N}$ (Fig. 2).

Sedimentation from the Late Kimmeridgian to Middle Berriasian was characterized by shallow lagoonal and peritidal carbonates, organized in hierarchically stacked high-frequency sequences ("cycles"). These were most probably generated by orbitally forced sea-level change (Rameil, 2005). The amplitude of high-frequency sea-level changes was most probably very low (m-scale), as the

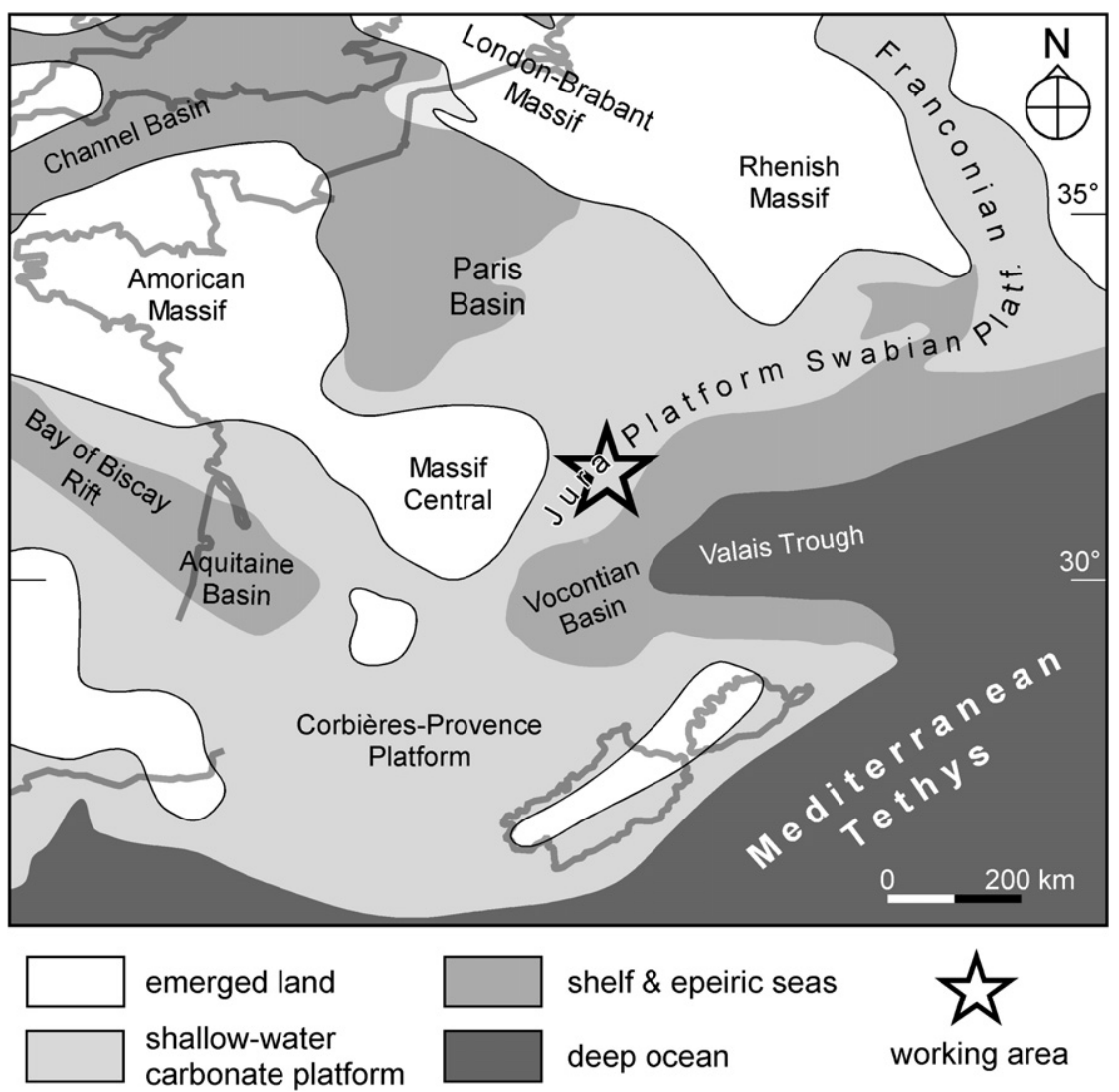

Fig. 2. Early Tithonian (ca. $150 \mathrm{Ma}$ ) palaeogeography of western and central Europe. After Thierry (2000). 
Kimmeridgian to Early Berriasian period is assumed to represent a greenhouse period in Earth's history with no, or only small, volumes of polar ice (Rameil, 2005; Husinec and Read, 2007).

\section{Methods}

The approach and nomenclature applied for outcrop-based, highresolution sequence-stratigraphic interpretation follow Strasser et al. (1999). Depositional sequences of different scales are interpreted from detailed field work, section logs and microfacies analysis. The smallest cycle of environmental change recognizable in the rock record is called elementary sequence. It is the basic architectural element that composes small-scale, medium-scale, and large-scale sequences, all of which again show characteristic facies evolutions. The stacking of theses sequences frequently shows a hierarchical pattern. For the present study, five sections in the Swiss and French Jura Mountains with a total thickness of $620 \mathrm{~m}$ were logged and studied bed by bed, locally in $\mathrm{cm}$ increments if necessary. The small-scale and mediumscale sequences identified in these sections have been interpreted to reflect the short and long eccentricity cycle of Earth's orbit (100 and 400 ka period), respectively. Large-scale sequences compare to "thirdorder" sequences (cf. Schlager, 2005). The complete, detailed section panels and sequence stratigraphic interpretations are published in Rameil (2005).

Each of the 776 rock samples were cut and slabs were etched with diluted (10\%) hydrochloric acid. 582 thin sections were prepared. Rock slabs and thin sections were examined using reflected and transmitted light microscopy, respectively, to determine depositional facies and diagenetic alteration. Twelve samples from dolomitized carbo- nates were prepared for cathodoluminescence (CL) microscopy. Analysis was carried out with a CITL MK3A cathodoluminescence unit (gun voltage $17 \mathrm{kV}$, gun current $450 \mu \mathrm{A}$ ).

Sixty-five samples that represent three different dolomite caps were selected for stable-isotope analysis (oxygen and carbon). Rock powders were extracted with a dentist drill, avoiding large bio/ intraclasts or veins. Under favourable conditions, this "modified whole-rock" analysis has shown to be representative for the overall isotopic signature, excluding biological fractionation and diagenetic signatures (Plunkett, 1997). Sample powders were then homogenized and reacted with $100 \%$ phosphoric acid at $90{ }^{\circ} \mathrm{C}$. Isotopes were measured with a Finnigan Delta Plus XL mass spectrometer with an attached Gasbench II and a PAL autosampler in continuous flow mode in the stable isotope laboratory of the University of Lausanne (Switzerland). All delta values are calibrated to the Vienna PeeDee Belemnite (VPDB) standard and expressed as per mil values.

\section{Results}

\subsection{Dolomites}

Three different types of early diagenetic dolomite are distinguished based on crystal geometry (Sibley and Gregg, 1987) and size, stable isotope signature, and the geometry and stratigraphic position of dolomite bodies.

\subsubsection{Type-1 dolomite ("matrix dolomite")}

Type-1 dolomite (Fig. 3 ) is defined by matrix-replacive, medium grained (50-300 $\mu \mathrm{m})$, euhedral (planar-e type) to subhedral (planar-s
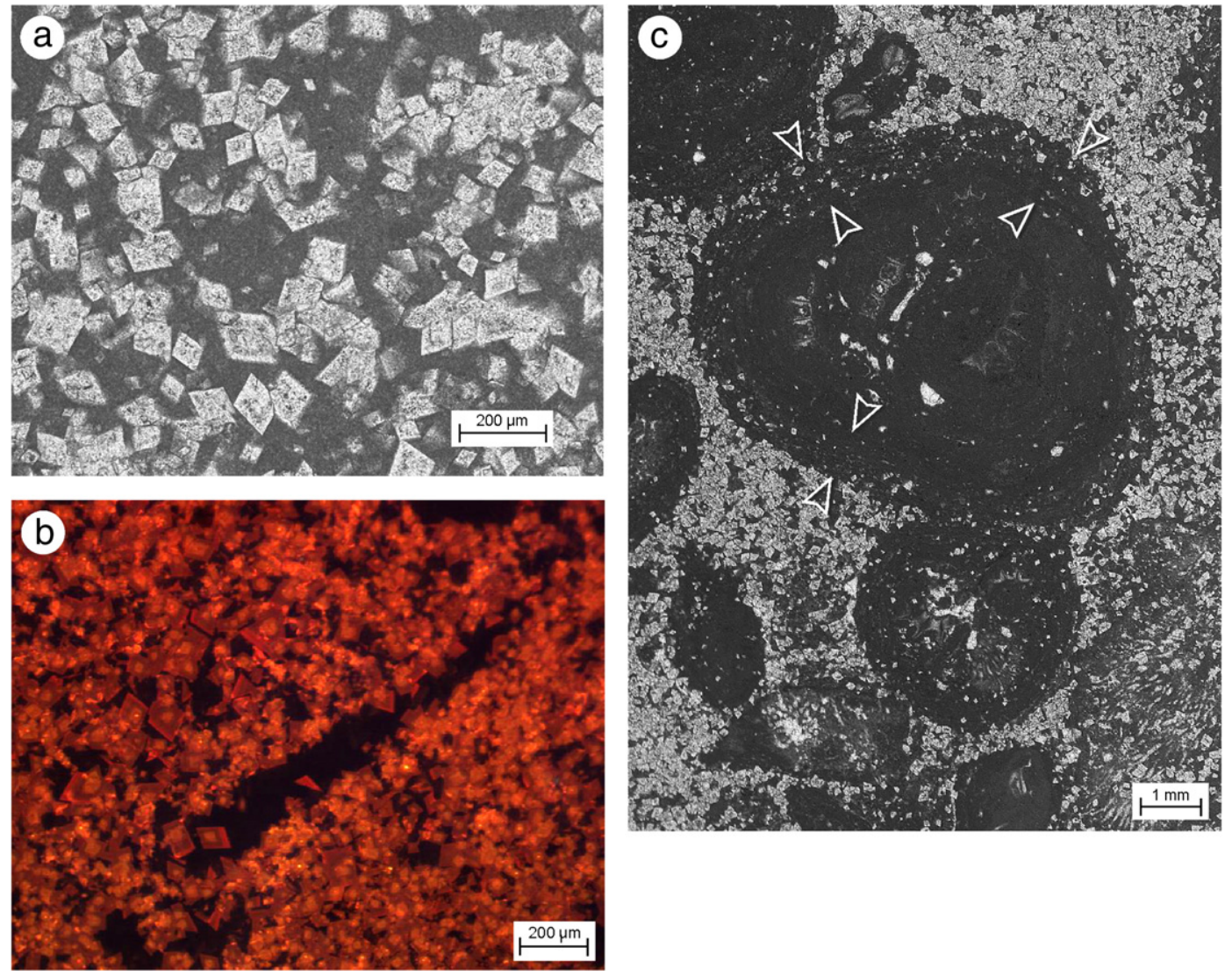

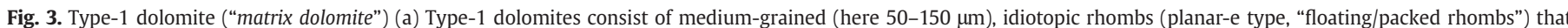

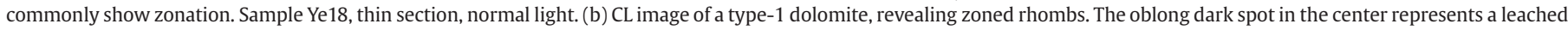

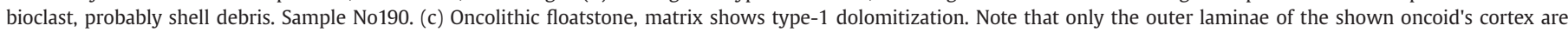

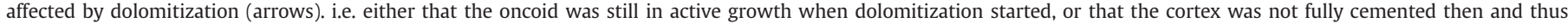
permeable for the dolomitizing fluid. Sample Av54, thin section, normal light. 
type) dolomite rhombs (Fig. 3a). The intensity of dolomitization varies from isolated rhombs floating in the micritic matrix to idiotopic and hypidiotopic mosaic texture. In cathode luminescence (CL) analysis, type-1 dolomites commonly reveal zonation (different shades of red for the outer zones with the core displaying a brighter red CL, Fig. 3b). Under plain light, this may show as "cloudy center-clear rim" geometry (Fig. 3a). The $\delta^{18} \mathrm{O}$ values of type- 1 dolomites range from -1.6 to $+0.7 \%$. Their $\delta^{13} \mathrm{C}$ values range from +1.8 to $+2.6 \%$.

Type- 1 dolomite forms an estimated $70-80 \%$ of the dolomitized rock volume in the measured sections. This type consistently occurs in stratiform geometries in the uppermost part of a shallowing-upward lagoonal/peritidal sequence ("dolomite caps", Fig. 4). The stratiform dolomite bodies typically show a sharp (partly erosive) upper contact surface and a more diffuse lower contact with the intensity of type-1 dolomitization gradually decreasing downwards and passing into dolomitized limestones and then pure limestones (graded shading in Fig. 4b). Similar dolomitization patterns in cyclic sediment succession have been described by Strasser (1988) and Montañez and Read (1992).

Dolomite caps occur in different stages of development; ranging from completely dolomitized rock successions up to $8 \mathrm{~m}$ thick, underlying a medium-scale sequence boundary and extending over several small-scale sequences (Fig. 4a, b), down to a slightly dolomitized single bed underlying a small or medium-scale sequence boundary (e.g., top small-scale sequence 18 in Fig. 4c). In the field, well-developed dolomite caps are easily recognizable due to their recessive weathering pattern and darker colour in comparison to the over- and underlying lagoonal and peritidal limestones. Microfacies at the diffuse lower contact frequently reflects (highly) restricted lagoonal environments. Higher in the dolomite cap, dolomitization is usually fabric-destructive, so that no microfacies features of the precursor rock are preserved. Yet, these dolomites are commonly platy and may show indicators for tidal flat environments (remains of lamination, birdseyes, and tepee structures). Here, type- 1 dolomites are frequently intercalated with type-2 dolomites, thus creating the laminated/platy aspect. In the uppermost part of a dolomite cap, leaching may occur.

\subsubsection{Type-2 dolomite ("tidal-flat dolomite")}

Type-2 dolomite (Fig. 5) consists of matrix-replacive, fine-grained (10-60 $\mu \mathrm{m})$, planar-e type dolomite rhombs. In comparison to type-1 dolomite ("matrix dolomite"), however, the rhombic crystal shape is relatively poorly defined (Fig. 5a). In CL analysis, type-2 dolomites exhibit a uniform, dark red colour (Fig. 5b).

Type-2 dolomitization occurs mainly in thin ( $\mathrm{mm}$ to $\mathrm{cm}$-scale, rarely thicker) layers of laminated sediments usually showing various signs of subaerial exposure (e.g., birds eyes, tepee structures, desiccation cracks; Fig. 4b). Beds of laminated type-2 dolomites, however, rarely occur isolated in the stratigraphic record but rather in alternation with type- 1 dolomites. The laminated aspect of the original tidal-flat sediments is preserved by alternations in dolomitization intensity and rhomb length (Fig. 5c) and usually best visible in the field on weathered rock surfaces (Fig. 5d). Within a dolomite cap, the relative abundance of type- 2 dolomite tends to increase upward. In terms of high-resolution sequence stratigraphy (Rameil, 2005), this means that type- 1 and type- 2 dolomites are predominantly found in stratigraphic intervals underlying small-scale and medium-scale sequence boundaries, with type-2 dolomites showing their highest relative abundance right below the sequence boundary (Fig. 4). The $\delta^{18} \mathrm{O}$ values of rocks that contain a mixture of type- 1 and type- 2
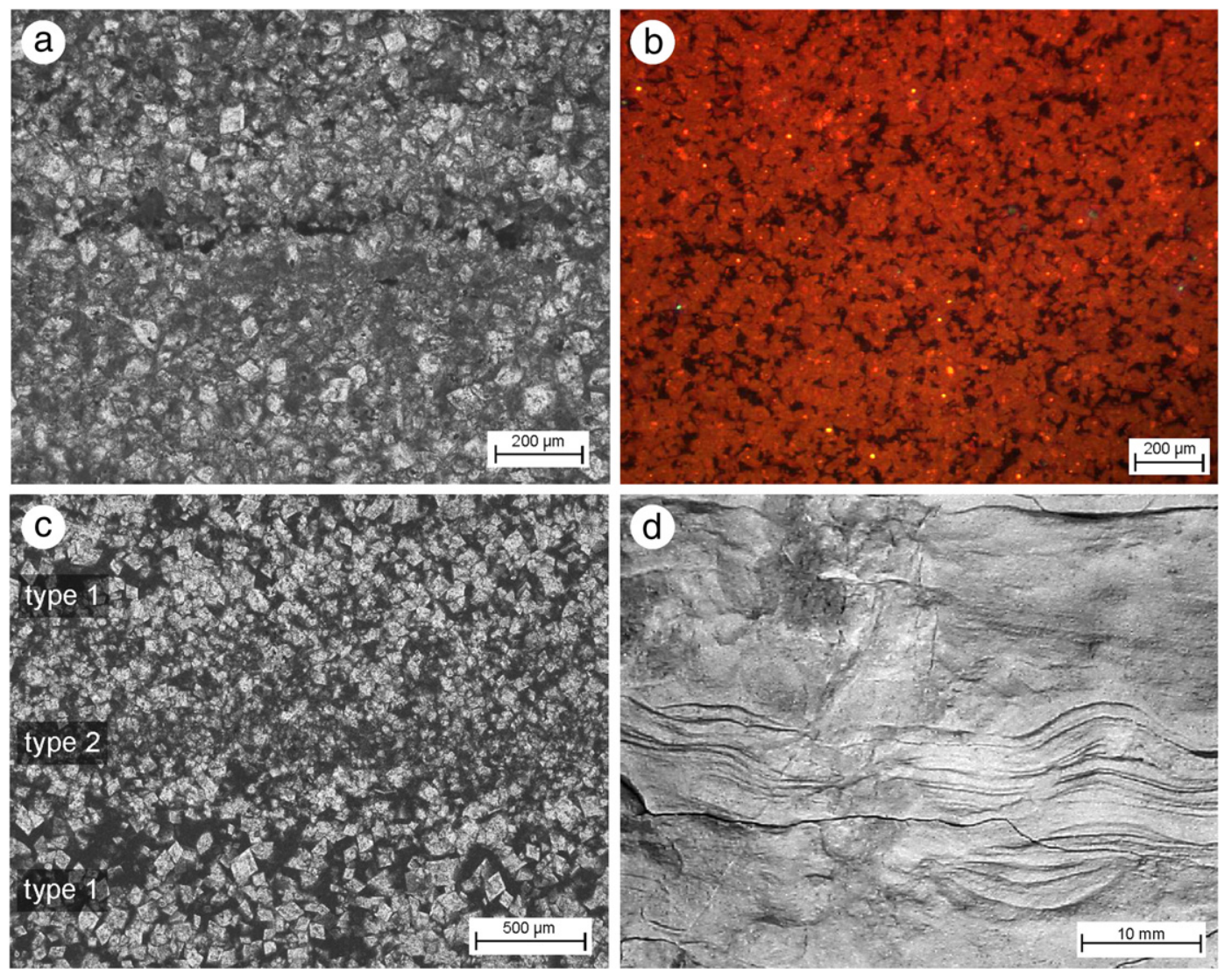

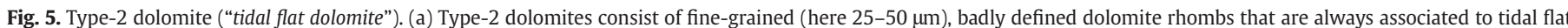

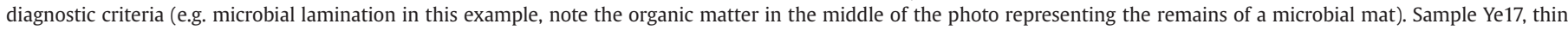

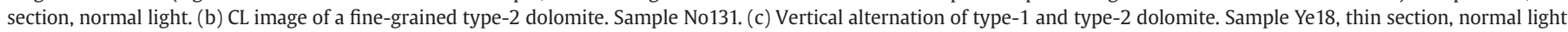

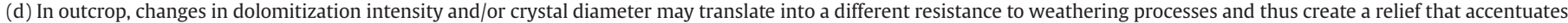
lamination. Crinkled microbial mats, La Dôle section, $121 \mathrm{~m}$. 


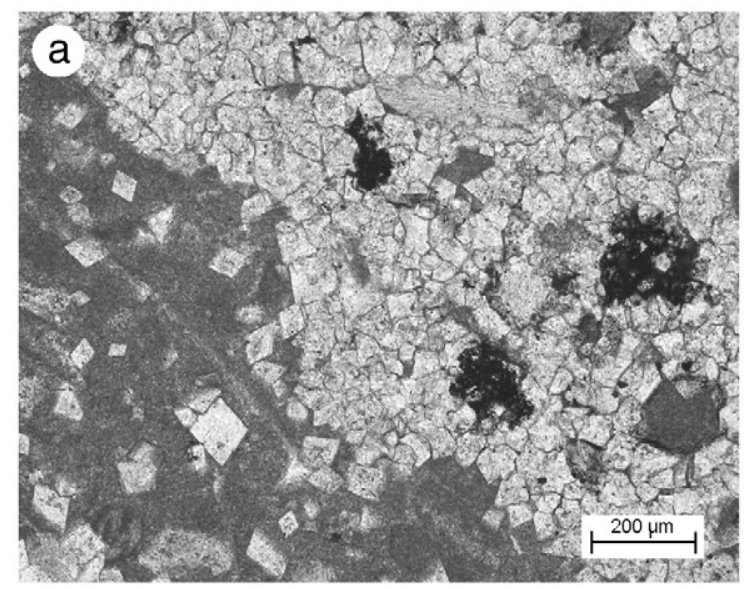

(b)
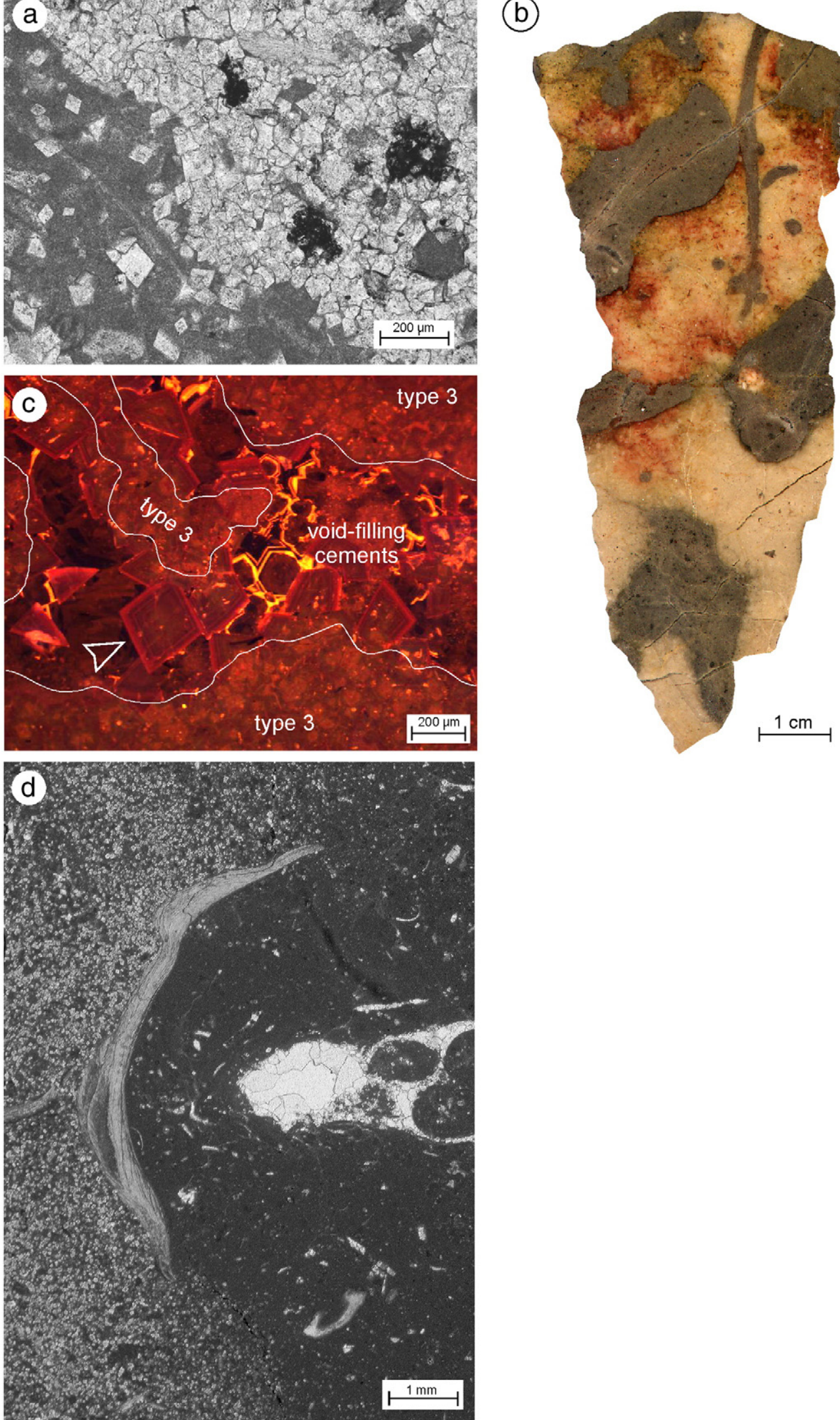

Fig. 6. Type-3 dolomite ("burrow dolomite"). (a) Many burrows are filled by medium- to fine-grained (here $40-100 \mu m$ ), hypidiotopic dolomite (planar-s type), commonly in association with blackened bio- or lithoclasts (dark patches). Sample No107, thin section, normal light. (b) Dolomitized burrows show a dark grey colour, contrasting with creamcoloured matrix. Etched rock slab, sample No70. (c) CL image of a dolomitized burrow. Early burrow-filling dolomite (type-3 dolomite) is characterized by a dense mosaic of rhombs that exhibit a brighter core. Large dolomite rhombs (arrow) and bright, hexagonal calcite crystals in the center represent later, void-filling cements. Sample No115. (d) Dolomitic halo radiating out from a dolomitized burrow. The burrow is located to the left out of the picture. In the center, the dolomitization front was abruptly blocked by a bivalve shell, whereas it is clearly of diffuse character above and below the obstacle. Sample No277, thin section, normal light. 


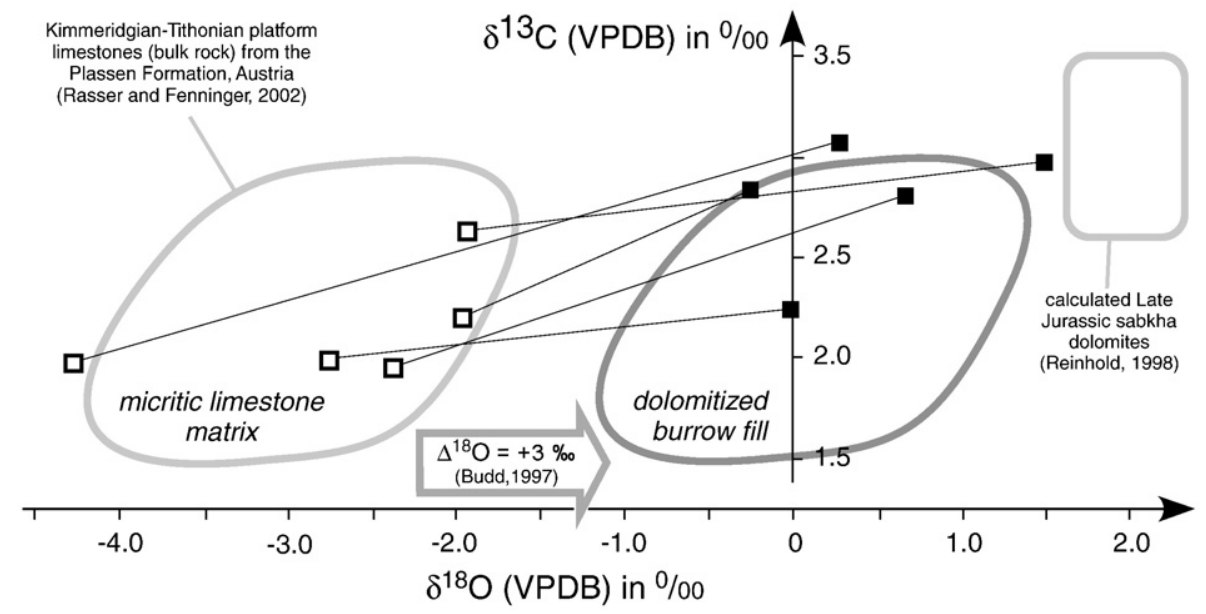

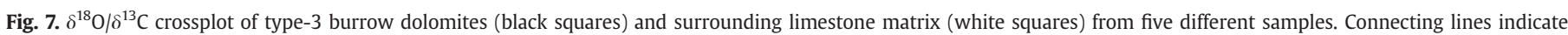

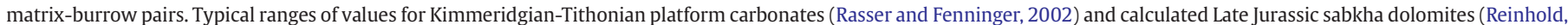

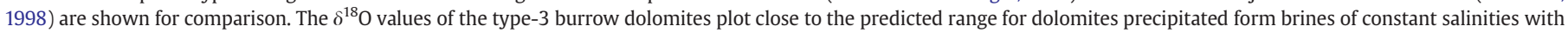
respect to the sea water in which the limestone matrix formed $\left(\Delta^{18} \mathrm{O}_{\text {dol-cal }}=+3 \%\right.$, Budd, 1997; dark grey field). See text for discussion.

dolomites range from -1.2 to $+2.0 \%$. Their $\delta^{13} \mathrm{C}$ values range from +1.3 to $+3.1 \%$. There is one single outlier from this cluster at $-4.0 \%$ 。 $\delta^{18} \mathrm{O}$ and $+1.3 \% \circ \delta^{13} \mathrm{C}$.

\subsubsection{Type-3 dolomite ("burrow dolomite")}

Type-3 dolomite (Fig. 6) is a replacive, fine- to medium grained (20-100 $\mu \mathrm{m}$ ), predominantly planar-s type dolomite (Fig. 6a). Type-3 dolomitization occurs in patches of burrow-like outline (Fig. 6b). The rock texture is similar to the "grey pseudobreccias" described by Horbury and Qing (2004) from the Carboniferous of the Lake District (U.K.), and to the dolomite-mottled Ordovician Tyndall Limestone from Manitoba, Canada (Gingras et al., 2004). Type-3 dolomites commonly exhibit a similar zoned CL pattern as type-1 dolomites, consisting of a brighter core surrounded by a dark red rim (Fig. 6c).

The dolomitized patches show relatively sharp dolomite-matrix boundaries. A "dolomitic halo" (Gingras et al., 2004), however, is frequently observed. It consists of a few mm-wide zone of floating dolomite rhombs that rapidly decrease in numbers towards the surrounding calcitic matrix (cf. Fig. 6a, d). Within the dolomitized patches, reddish iron-oxide staining or blackened (bio)clasts (Fig. 6a) commonly occur. Due to this, the colour of dolomite patches may turn to rusty brown or dark grey in contrast to the cream-colored limestone matrix (Fig. 6b). Other typical inclusions in the patches are peloids and echinoderm debris that were either dolomitized only weakly or not at all. At the center of some dolomite patches elongated, tubular cavities are preserved that may be open or filled with calcitic sparite (Fig. 6c). Within the tubular cavities, the calcitic sparites may overlie sand-sized (bio)clastic carbonate grains. In these cases, the boundary surface usually is of geopetal character. In contrast to type- 1 and type- 2 dolomites, type- 3 dolomite can be found at any stratigraphic position within a high-frequency sequence. Its occurrence is only linked to the presence of mud-supported limestones.

Both burrow-related type- 3 dolomites and the surrounding limestone matrix were measured in five rock samples in order to investigate similarities or differences in their isotope signatures (Fig. 7). The $\delta^{18} \mathrm{O}$ values of type- 3 dolomites range from -0.3 to $+1.5 \%$ and from +2.2 to $+3.1 \%$ for $\delta^{13} \mathrm{C}$. Oxygen values of matrix limestones plot between -4.3 and $-1.9 \%$. Their $\delta^{13} \mathrm{C}$ values range from +2.0 to $+2.6 \%$.

\subsubsection{Void-filling dolomite cements}

Void-filling dolomite cements occur in less that $1 \%$ of the rock volume. They consist of coarse (up to $200 \mu \mathrm{m}$ ) euhedral to subhedral dolomite rhombs. Under CL, they show zonation but are clearly differentiated from type- 1 dolomites by their larger size and the lack of a core that is defined by a brighter CL colour. They are usually limited to (probably primarily) open cavities in burrow systems where they grow centripetally from the margin of the cavity (Fig. 6c). No stable isotope analyses have been carried out on the void-filling cements.

\subsection{Dedolomites}

\subsubsection{Type-1 dedolomite}

Type- 1 dedolomite consists of rhomb-shaped pores that are either completely filled with calcitic microsparite (cements) or, more frequent, consisting of a thin, rhomb-shaped crystalline rim with a micritic fill (Fig. 8a). If still present, the crystalline rim tends to be very thin $(<10 \mu \mathrm{m}$; Fig. $8 \mathrm{a})$. Most rhombs have one or more of their corners missing. In (former) crystal geometry and size, all type-1 dedolomites correspond to type- 1 dolomites ("matrix dolomites"). Type- 1 dedolomites can be found in any stratigraphic position of the measured sections. Rock bodies of type- 1 dedolomite occur in $\mathrm{cm}$ to dm-scale, irregular ("patchy") geometries within lagoonal and peritidal limestones. Their distribution does seem not to follow any coherent pattern (Fig. 8e) and stratiform rock bodies, which are typical for other types of (de)dolomites described in this paper, were never found. Type-1 dedolomites were not specifically sampled for stable-isotope analysis.

\subsubsection{Type-2 dedolomite}

Type-2 dedolomites are completely recrystallized calcitic rocks showing a highly variable appearance. The common factor, however, is that, in contrast to type- 1 dedolomites, traces of rhomb-shaped crystals are rare and only locally preserved. Type-2 dedolomites are always sparitic with widely varying crystal size and may be of sucrosic character (Fig. 8b). A special subtype of type-2 dedolomite is cellular/ vuggy sparite (Rauhwacke or cornieule). Vugs are from $1 \mathrm{~mm}$ to $2 \mathrm{~cm}$ in diameter and may be empty or filled with red-brown, only partly lithified clay. Locally, these type-2 dolomites may show remains of tidal-flat like lamination (Fig. 8c, d).

Type-2 dedolomitization occurs in stratiform geometries from a few $\mathrm{dm}$ to several $\mathrm{m}$ of thickness. It is always associated with largescale sequence boundaries. Thicker bodies of type- 2 dedolomites are usually accompanied by brecciation, either as brecciated pockets within the dedolomites or a massive breccia-layer overlying the dedolomites. If present, type- 2 dedolomites are predominantly found 

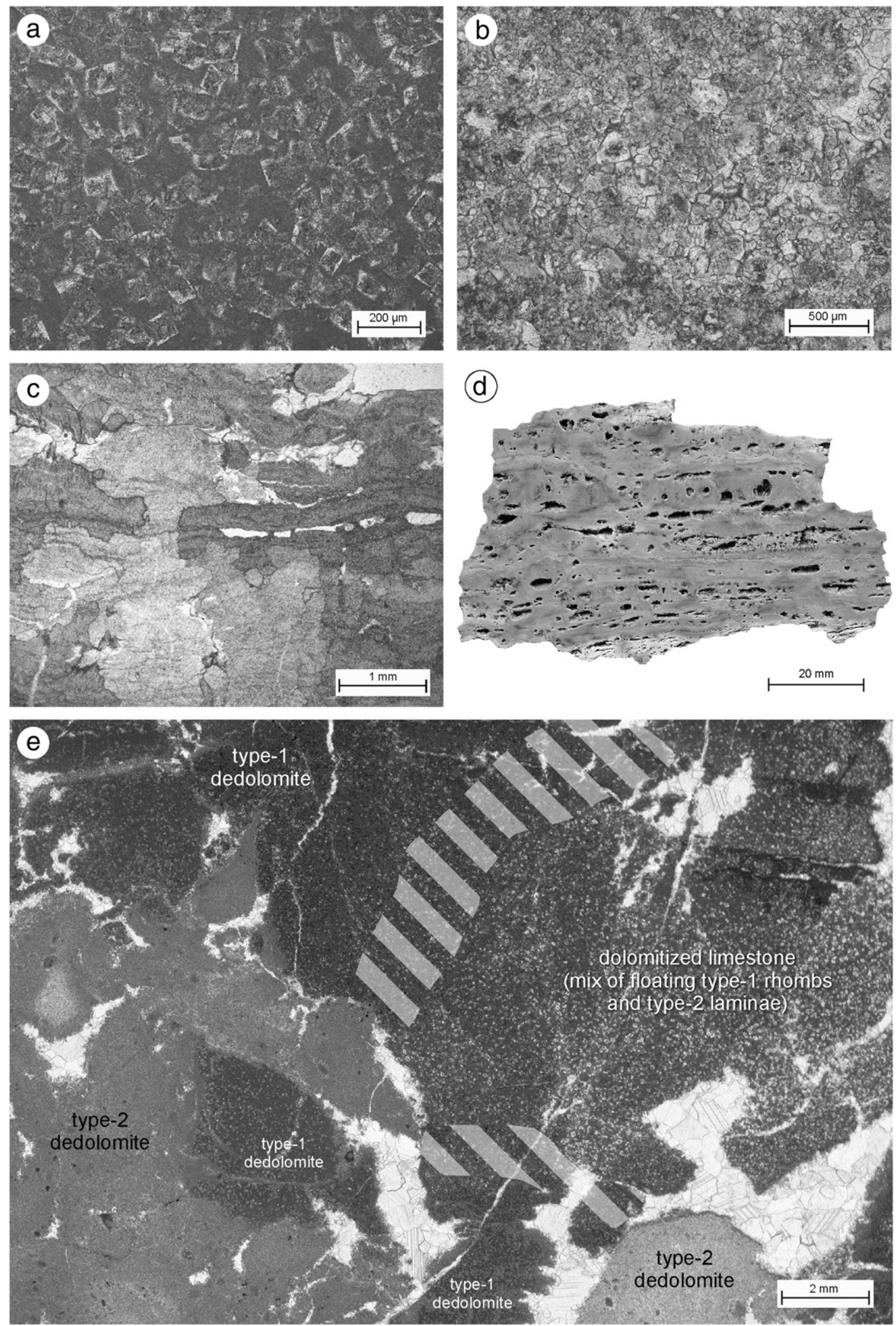

Fig. 8. Dedolomitization. (a) Type-1 dedolomite. Sample No84, thin section, normal light. (b) Structureless type-2 dedolomite. Sample Do196, thin section, normal light. (c) Type-2 dedolomite, showing ghost structures of a precursor algal laminite. Sample Do189, thin section, normal light. (d) Laminated cornieule from the lowermost Berriasian. Lamination is interpreted to indicate tidal flat depositional environments. Sample Do195, etched slab. (e) Spatial relations between dolomitized limestone, type-1 dedolomite and type-2 dedolomite. The passage from dolomitized limestone to type-1 dedolomite is gradual (hatched area). Sample No200, thin section, normal light.

in Upper Tithonian and Lower Berriasian rocks (La Dôle, and specifically Le Lieu section, Fig. 1). Yet, they are completely absent in carbonates of Late Kimmeridgian age.
The $\delta^{18} \mathrm{O}$ values of type-2 dedolomites are strongly depleted $(-6.1$ to $-3.6 \%$ ). Their $\delta^{13} \mathrm{C}$ values are highly variable and range from as low as -5.6 to $+0.9 \%$ 。 $\delta^{13} \mathrm{C}$. 


\section{Discussion}

\subsection{Dolomitization - models and evidence}

With respect to the discussion of the dolomites and their geochemical data presented in this study, the following considerations are of importance: Isotopic analyses carried out in this study represent samples consisting either of pure (bulk) dolomite, or of an admixture of dolomite, calcareous matrix, and microfossils were analyzed (partial dolomitization). In the latter case, the resulting isotopic composition therefore represents a geochemical average of all phases present in the sample. The limitations of this approach are acknowledged. Nevertheless, following previous workers, bulk rock analyses have been used successfully to identify horizons of early diagenetic alteration (e.g., exposure surfaces, evaporation on tidal flats, meteoric vadose diagenesis) in Jurassic and Cretaceous carbonates (Joachimski, 1994; Plunkett, 1997; Fouke et al., 2005).

Obviously, $\delta^{18} \mathrm{O}$ of dolomites should not be directly compared with $\delta^{18} \mathrm{O}$ of limestones as the equilibrium fractionation between dolomite and water at low temperatures is unknown. A common method to avoid this problem is to calculate the equilibrium isotopic composition of calcite for a particular fluid and temperature, and then assume a value for $\Delta^{18} \mathrm{O}_{\text {dol-cal }}\left(=\delta^{18} \mathrm{O}_{\text {dolomite }}-\delta^{18} \mathrm{O}_{\text {calcite }}\right.$ on the VPDB scale), in order to derive an estimate of the equilibrium isotopic composition of dolomite from that fluid at that temperature (Budd, 1997). Estimations of $\Delta^{18} \mathrm{O}_{\text {dol-cal }}$ values ranging from $2 \%$ o to $6 \%$ have been put forward by a number of authors (cf. review in Budd, 1997), but a mean value that is widely accepted and applied to the data shown here is $3 \%$.

Three types of dolomite and two types of dedolomite have been described in the present study. Below, the field and petrographic evidence as well as the geochemical data available are placed in their larger context and published previous work and hypotheses are tested and discussed.

Type-1 dolomites, forming stratiform dolostone bodies with diffuse lower and sharp, erosive upper boundaries (Fig. 4b) fit well into a reflux-type model (Warren, 2000). This is also supported by their slightly elevated $\delta^{18} \mathrm{O}$ values (Figs. 4a, b and 9). The original model of Newell et al. (1953) and Adams and Rhodes (1960) proposes dense hypersaline brines sinking from evaporitic lagoons near the coastline into the platform and a resulting dolomitization of the underlying limestones. Indicators for the former presence of evaporites, however, are rare throughout the studied sections and only become more important from the Latest Tithonian onwards (Dôle and Lieu sections; cf. Rameil, 2005). Nevertheless, circumstantial evidence

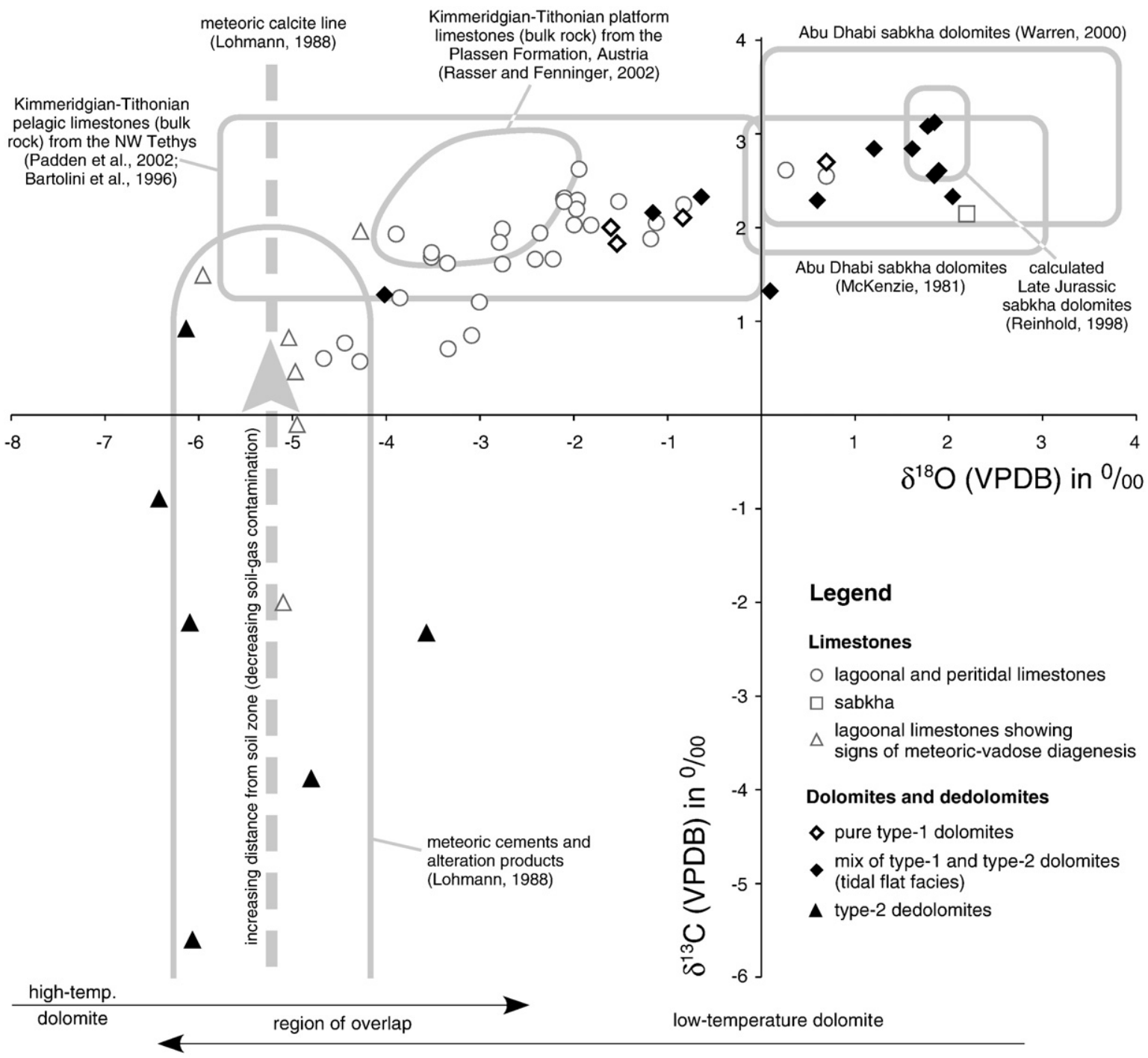

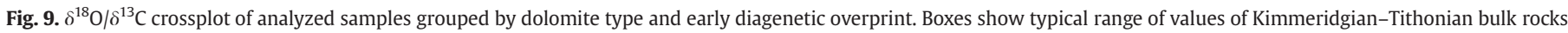

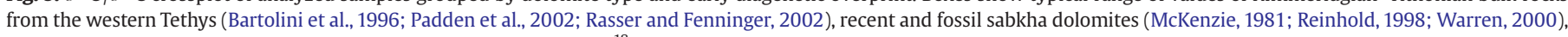

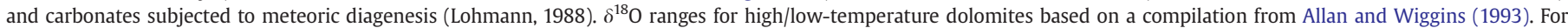
discussion refer to text. 
for evaporated brines causing type-1 dominated dolomite caps comes from stable-isotope stratigraphy. Fig. 4a displays a positive shift in $\delta^{18} \mathrm{O}$ in the order of $4 \%$ at the base of the dolomite cap, followed by relatively constant values around $+1 \%$ over the entire dolomitized interval. If a hypothetical $\delta^{18} \mathrm{O}$ baseline of lagoonal limestones is established by linking the limestones underlying and overlying a dolomite cap (thick dashed lines in Fig. 4), dolomites precipitated from brines with near-normal marine seawater salinity should show the $\Delta{ }^{18} \mathrm{O}_{\text {dol-cal }}$ offset of $+3 \%$ ( thin dashed lines in Fig. 4). The oxygen isotopic composition of dolomite is usually derived from the dolomitizing fluid rather than from the precursor rock (Land, 1980; Banner et al., 1988). Consequently, dolomites with enriched oxygen isotopic values are likely to be precipitated from ${ }^{18} \mathrm{O}$-enriched (evaporitic) brines (Melim and Scholle, 2002). Dolomites showing $\delta^{18} \mathrm{O}$ values that exceed $\Delta{ }^{18} \mathrm{O}_{\text {dol-cal }}>3 \%$ ore thus interpreted to represent evaporated brines. This is clearly the case for most of the dolomite cap in Fig. 4a. Obviously, evaporation was insufficient for the precipitation of gypsum and/or anhydrite. In conclusion, circumstantial geochemical evidence might point indeed to a reflux origin of type-1 dolomites but obviously, this working hypothesis must be discussed in the context of previous work.

Simms (1984) and Kaufman (1994) proposed that reflux systems can work with sea water of only slightly increased salinity. Simms (1984) modelled reflux in carbonate platforms with brines of $42 \%$ salinity and predicted the existence of a reflux system in the Great Bahama Bank that was eventually documented (Whitaker and Smart, 1993; Whitaker et al., 1994). Sun (1994) reasoned that during ice-free periods with small amplitudes in high-frequency sea-level change, carbonate platforms switch to keep-up mode over tens of millions of years, because their potential of carbonate production exceeds platform subsidence in most cases. Prograding platforms create vast platform-top areas with extensive supratidal domains inundated during storm surges. In these settings, mesosaline fluids (35 to $120 \%$, i.e., below gypsum saturation) are known to form the source for reflux brines. Indeed, in the studied dolomite-capped sequences, elevated salinities are indicated by the presence of restricted marine carbonate facies and biota whereas massive evaporite deposits are absent. Similar settings were described from the Early Jurassic of Gibraltar
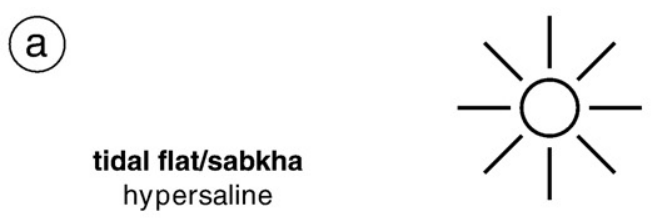

\section{(semi)arid climate}

normal marine to restricted lagoon

stenonohaline-mesosaline

(b) open marine

stenonohaline

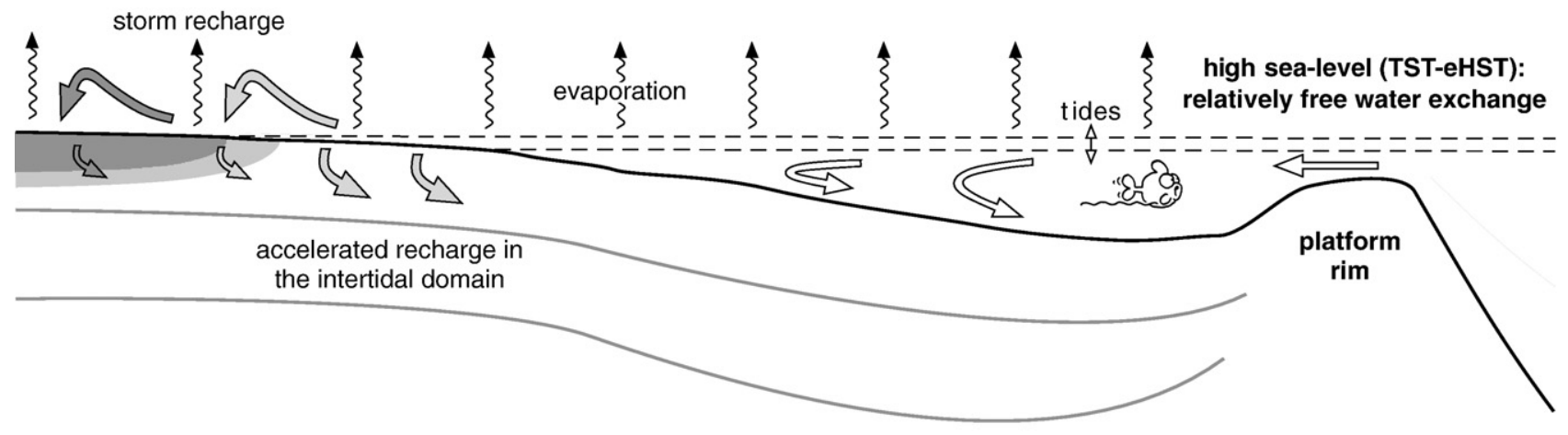

\author{
tidal flat/sabkha \\ hypersaline
}

highly restricted lagoon

mesosaline-hypersaline open marine

stenohaline

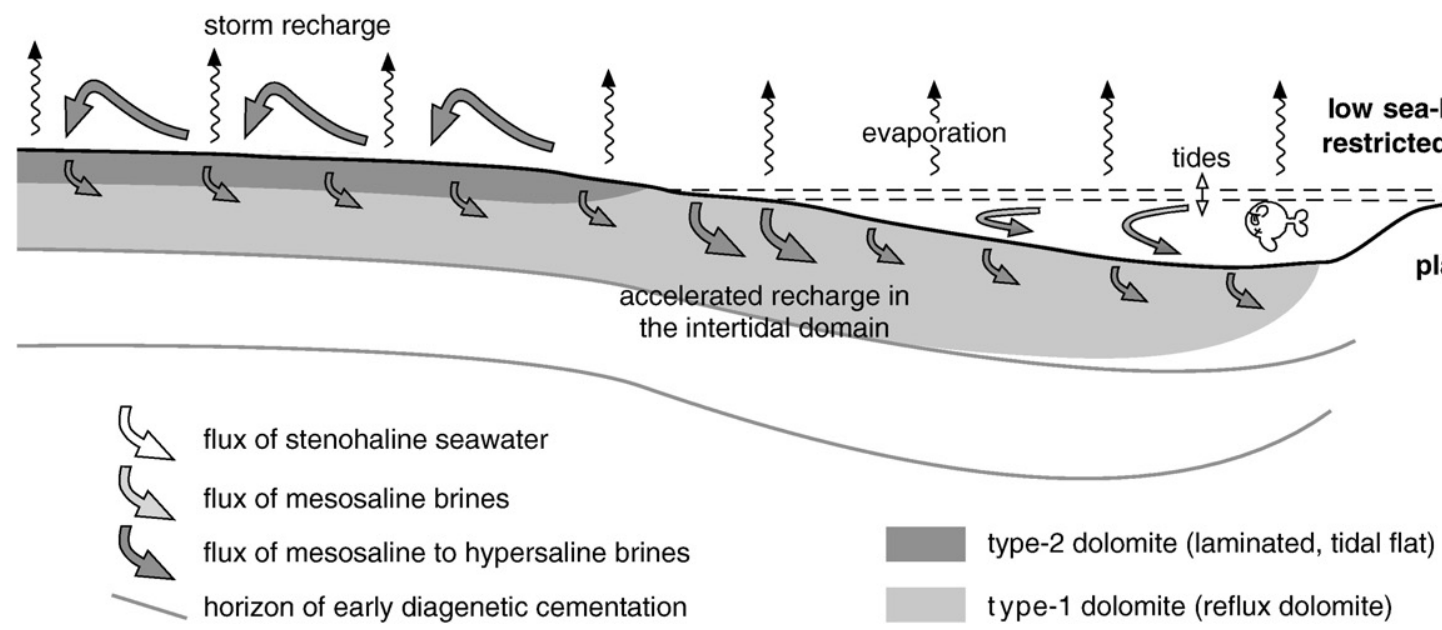

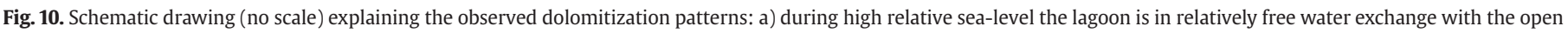

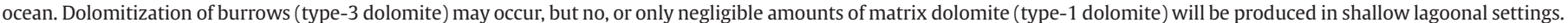

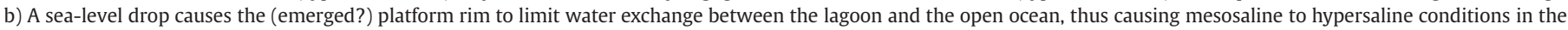

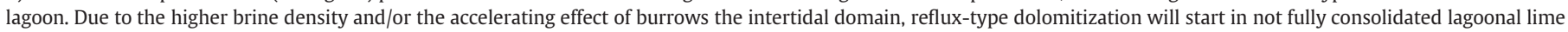

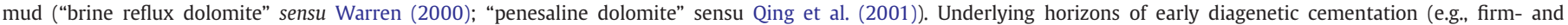
hardgrounds) may act as flow barriers with respect to the percolating brine, leading to stratiform dolomitization. See text for discussion. 
(Qing et al., 2001) and from the Permian Capitan Formation of Texas and New Mexico (Melim and Scholle, 2002). Qing et al. (2001) referred to this type of dolomitization as "penesaline dolomites", in agreement with Adams and Rhodes' (1960) term for evaporated sea water with salinities varying from 72 to $199 \%$.

Furthermore, the dolomite cap shown in Fig. 4a has a firm/ hardground as a lower boundary that forms a sharp boundary between dolomites/lagoonal limestones and high/low $\delta^{18} \mathrm{O}$ values respectively (Fig. 4a, 126.3 m). This stands in clear contrast to the commonly observed downward-transition from type-1 dolomite to a dolomitized limestone with floating rhombs and a gradual decrease in $\delta^{18} \mathrm{O}$ (cf. Warren, 2000). This gradual transition is interpreted to reflect a percolation of the dolomitizing brines from above, with a decreasing intensity of dolomitization downward. In the case of the dolomite cap shown in Fig. 4a, the syn-depositionally lithified surface apparently acted as a seal with respect to a downward-directed flow of dolomitizing fluid. This is considered as clear evidence for the early diagenetic nature of the type-1 dolomites.

Accepting the concept of penesaline dolomitization by seepage reflux, an open question remains: Why are the studied sections characterized by a succession of m-thick dolomite caps as opposed to one massive body of reflux dolomite? A suitable hypothesis is that the observed pattern was generated by a repeated, pulsed nature of dolomitization. Mutti and Simo (1994) and Qing et al. (2001) proposed that repeated high-frequency sea-level fall is able to drive pulses of dolomitizing fluids into the platform but this hypothesis is not without problem. Alternative mechanisms include storm recharge on tidal flats (Fig. 10) and the development of perched reservoirs in the intertidal domain twice a day (Fig. 11). According to Machel (2002), the efficiency of the reflux mechanisms differs between transgressive and regressive periods. This might imply that high-frequency sealevel changes affect dolomitization rates. During transgressive phases, water exchange between the platform top hydrofacies and the open sea is enhanced resulting in normal marine to slightly restricted lagoonal water masses and normal marine biota. With sea level falling, the water exchange with the open ocean becomes more and more restricted, the salinity of the lagoonal water increases and biota that are more tolerant to elevated salinities take over (Fig. 10b). Similar to modern settings, the platform rim probably consisted of a chain of reefal mounds and/or oolite bars (Détraz and Mojon, 1989; Meyer, 2000), and no complete isolation of the lagoon occurred. Nevertheless, under these circumstances salinity was elevated and a brine of sufficient density to start a reflux flow was generated. With the next transgression, water exchange re-established while a latent reflux (Jones et al., 2002) may have continued for a while. A reflux mechanism that is switched on and off by high-frequency sea-level changes would result in only shallow, but repeated infiltration horizons (F. Whitaker, pers. comm.) - creating repeated dolomite caps in a peritidal limestone succession such as the ones found in the measured sections.

The next dolomite type is referred to as Type-2. Type-2 dolomites occur as thin, laminated intercalations in type- 1 dolomites and are clearly associated with tidal-flat environments and/or subaerial exposure. These dolomites typically occur towards the end of a regressive trend and/or delimit small-scale sequences (Fig. 4b). Bulk isotope data containing type- 1 and type- 2 dolomites show elevated $\delta^{18} \mathrm{O}$ values that in part plot in the range of modern Persian Gulf sabkha dolomites (McKenzie, 1981; Warren, 2000) and close to the pole of calculated Upper Jurassic sabkha dolomites (Reinhold, 1998; Fig. 9). Genuine sabkha deposits, however, are rare in the studied sections (Rameil, 2005). Nevertheless, elevated $\delta^{18} \mathrm{O}$ ratios indicate the importance of evaporation processes in the generation of type- 2 dolomites.

The influence of evaporitic brines is also demonstrated in the dolomite cap shown in Fig. 4b, featuring $\delta^{18} \mathrm{O}$ excursions that reach about $6 \%$ above the hypothetical base line representing dolomites precipitated
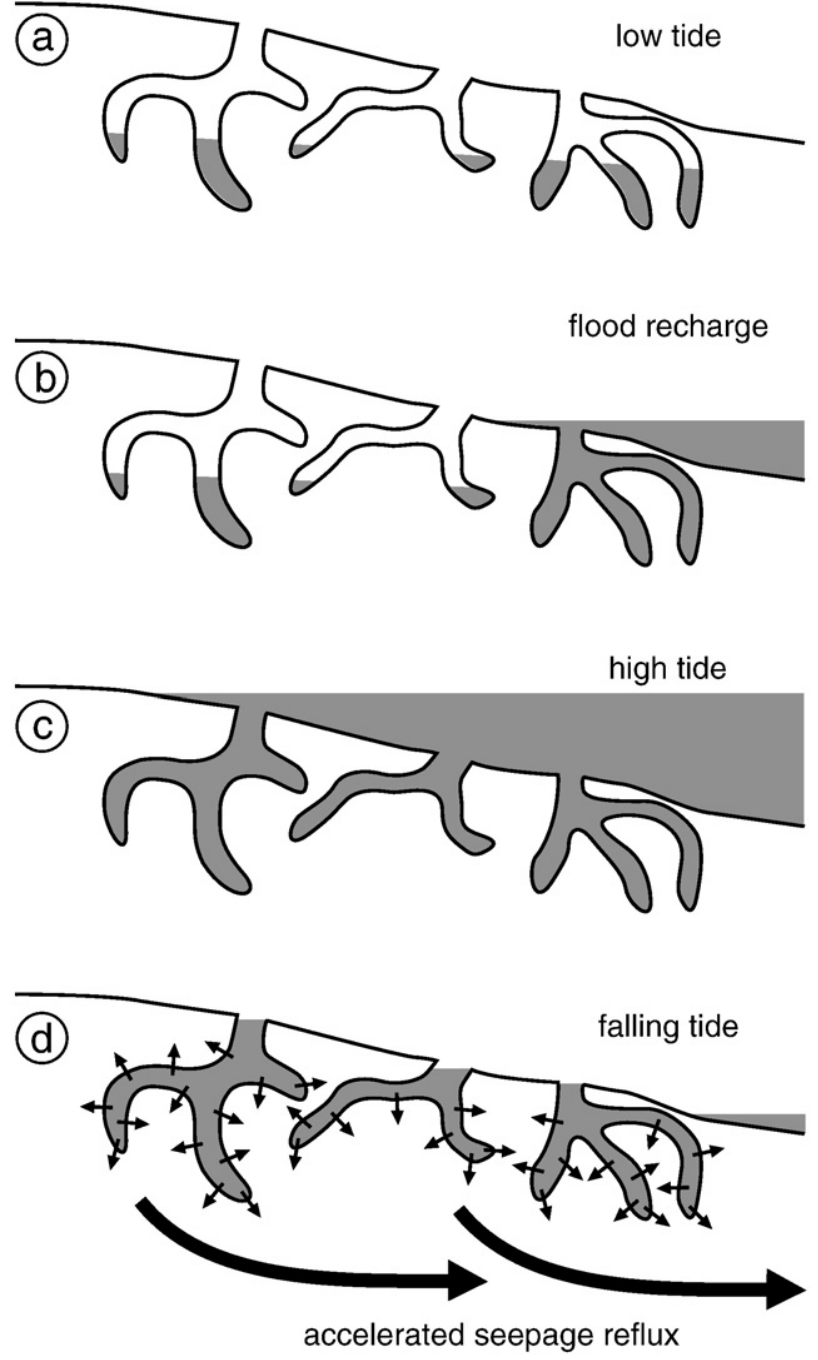

Fig. 11. Accelerating effect of bio- and/or rhizoturbation on seepage reflux: burrows and hollow root debris, partly empty at low tide (a), are rapidly filled by flood tide (b-c) forming a perched reservoir ensuring percolation of dolomitizing fluid (sea water of elevated salinity) during falling tide (d). After Baltzer et al. (1994).

from normal-marine seawater. Note that each of the two isotope maxima is preceded by a short plateau phase during which $\delta^{18} \mathrm{O}$ values of the dolomitized rocks are very close to the $\Delta^{18} \mathrm{O}_{\text {dol-cal }}$ offset of $+3 \%$ o (Fig. $4 \mathrm{~b}$ ). Plateau phases coincide with pure type- 1 dolomites samples probably generated by shallow reflux of sea water with moderately elevated salinities. In contrast, oxygen-isotope maxima appear where type-2 dolomites are contained in the bulk material analyzed and appear in tidal-flat facies (algal lamination, tepee structures, bird's eyes; cf. Fig. 4b). Similarly, a dolomitized bed of supratidal, multicoloured breccia coincides with a single positive $\delta^{18} \mathrm{O}$ peak in the Cirque des Avalanches section (Fig. 4c). It is thus assumed that the pronounced $\delta^{18} \mathrm{O}$ excursions $\left(\Delta^{18} \mathrm{O}_{\text {dol-cal }}>+3 \%\right.$ ) indicate peaks of evaporative conditions that produced dolomitizing fluids of elevated salinity. The volumetrically insignificant and restricted appearance of type-2 dolomites in tidal-flat facies is in agreement with dolomitization processes that took place directly at, or just beneath the sediment surface. But what is the evidence for this assumption?

On modern tidal-flats, laminated, cm-thick dolomite crusts develop directly underneath the sediment surface (e.g., Shinn et al., 1965; Carballo et al., 1987; Mazullo et al., 1995). Dolomite crystals in these crusts are small, euhedral to subhedral rhombs which range in size from $<1$ to $5 \mu \mathrm{m}$ (Budd, 1997). Oxygen-isotope values of Holocene dolomite crusts range from +1.5 to $+3.2 \%$ (Carballo et al., 1987; 
Mazullo et al., 1995) similar to the values measured in Upper Jurassic tidal-flat dolomites (Fig. 9). In addition, these dolomite crusts share many similarities in terms of facies, texture, isotopic signature, and average crust thickness with the Upper Jurassic type-2 dolomites. Accepting that the arguments brought forward here represent no conclusive evidence, it is tentatively suggested that type- 2 dolomites represent an analogue to penecontemporaneous dolomitic crusts as known from Holocene tidal flats. The formation of Holocene and recent tidal-flat dolomites is accomplished by active tidal pumping of sea water of normal to slightly elevated salinity. Evaporative pumping and/or sulphate reduction may also play a role (Carballo et al., 1987). Analogous mechanisms are assumed for the formation Late Jurassic type-2 dolomites. With (semi-)arid climate (Rameil, 2005), evaporative pumping may have played a more important role on the Late Jurassic tidal flats than in their modern counterparts described in literature. Also, storms may have driven lagoonal water onto the adjacent tidal flats where it was concentrated by evaporation and contributed to the formation of thin dolomite crusts (Fig. 10a).

Type-3 dolomites are the last of the three classes observed here that require an interpretation. The occurrence of various skeletal and non-skeletal grains within type-3 dolomites, and the existence of linear cavities in the center of the dolomite patches (Fig. 6c) suggest a replacement of a precursor burrow fill. In contrast to type- 1 and type2 dolomites, that are bound to surfaces with a clear sequence stratigraphic significance, burrows filled with type-3 dolomite can be found in mud-supported sedimentary rocks throughout a shallowing-upward sequence.

Type-3 dolomites and micritic limestones of the surrounding matrix both plot in clusters that differ in average by about $3 \% \circ \delta^{18} \mathrm{O}$ (Fig. 7). Based on the assumption of a $\Delta{ }^{18} \mathrm{O}_{\text {dol-cal }}$ of $+3 \%$ (Budd, 1997) this implies that both type-3 dolomites and micritic limestone matrix were most probably precipitated from sea water with a similar isotopic composition. The limestone matrix data are typical for Late Jurassic limestones precipitated from normal marine sea water. The slightly elevated $\delta^{13} \mathrm{C}$ values of the burrow-fill dolomites, relative to the surrounding limestone matrix (Fig. 7), may be due to the relative enrichment of ${ }^{13} \mathrm{C}$ in dolomite with respect to co-genetic calcite (approx. 1\%。; Sheppard and Schwarz, 1970) or point to organic matter.
Dolomitized burrows are a relatively widespread phenomenon and were, for example, described by Purser (1975), Gingras et al. (2004), and Horbury and Qing (2004). Burrowing organisms significantly alter the sediment substrates in various ways including biochemical modifications by the incorporation of localized, concentrated organic matter in the form of mucous or faecal pellets providing substrates for bacterial colonization (Gingras et al., 2004). Open burrows or burrows filled with coarse (bio)clastic material ("tubular tempestites"; Wanless et al., 1988) act as open conduits to the sediment-water interface but can maintain a variety of chemical microenvironments extending several $\mathrm{cm}$ 's into the sediment surface (Gingras et al., 2004). Close to the surface and in burrows open to the sediment-water interface, the microbial oxidation of organic material (respiration) produces $\mathrm{CO}_{2}$. Depending on geochemical conditions, increased $\mathrm{CO}_{2}$ activities enhance carbonate dissolution during early diagenesis. Furthermore, free $\mathrm{SO}_{4}^{2-}$ ions inhibit dolomite precipitation and may lower the $\mathrm{Mg} / \mathrm{Ca}$ ration by bonding with $\mathrm{Mg}^{2+}$ ions (Fig. 12). From modern settings, it is known that dolomite formation preferably occurs under reducing conditions and induced by microbes (Vasconcelos and McKenzie, 1997; van Lith et al., 2003a,b). $\mathrm{CO}_{2}$ and $\mathrm{NH}_{3}$ are common products in this geochemical setting and both react with water. The reaction of ammonia $\left(\mathrm{NH}_{3}+\mathrm{H}_{2} \mathrm{O} \leftrightarrow \mathrm{NH}_{4}^{+}+\mathrm{OH}^{-}\right)$raises $\mathrm{pH}$ which, in turn, increases the activity of the bicarbonate ion $\left(\mathrm{HCO}_{3}^{-}\right)$ that favours the direct precipitation of dolomite (Lippmann, 1973; Gingras et al., 2004).

Under reducing conditions, $\mathrm{SO}_{4}^{2-}$ ions are consumed by sulphate reducing bacteria. This is the key to the early diagenetic precipitation of dolomite in burrow systems (Gingras et al., 2004). Under these geochemical conditions, dolomite crystals precipitate under microbial mediation (van Lith et al., 2003b). Metal enrichments in the organic burrow lining may additionally facilitate dolomite precipitation (Mirsal and Zankl, 1985). Dolomite precipitation may spread into the surrounding micritic matrix and thus create few mm-thick dolomitic zones of floating dolomite rhombs (Fig. 6a, d). As metal enrichments in organic burrow lining are very local sources of $\mathrm{Mg}^{2+}$ ions, type-3 dolomitization is limited to burrows and their direct vicinity (Gingras et al., 2004). Limestones with dolomitized burrows, however, may undergo subsequent type-1 dolomitization.
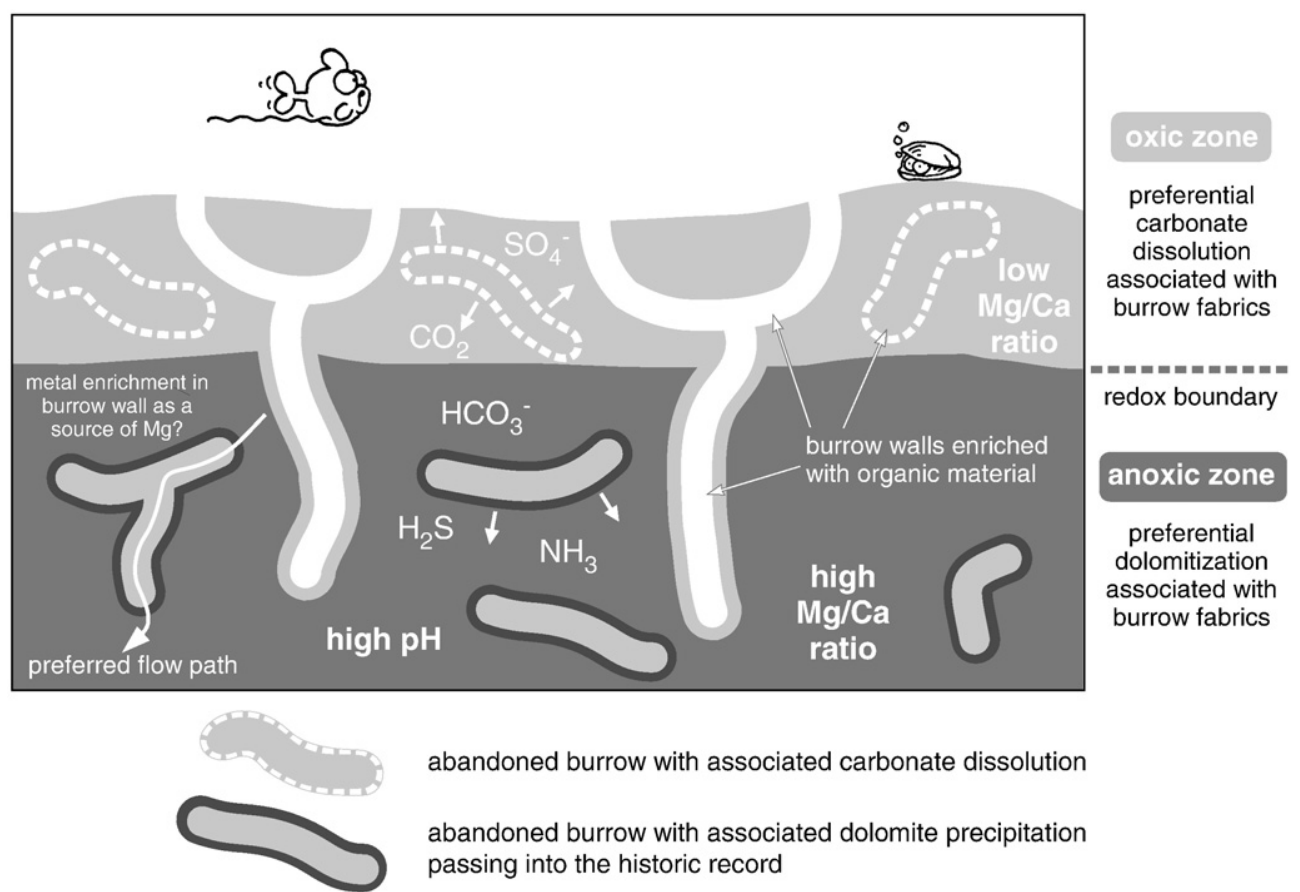

abandoned burrow with associated carbonate dissolution

abandoned burrow with associated dolomite precipitation passing into the historic record

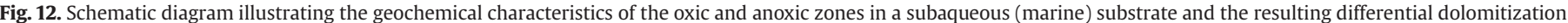
associated to burrows (type-3 dolomite). From Gingras et al. (2004), modified. For detailed explanation refer to text. 
With respect to the timing of dolomitization the following considerations are of importance. Dolomite mosaics with planar crystal boundaries (idiotopic crystals) are characteristic for the studied sections. According to Sibley and Gregg (1987) and Warren (2000), this indicates precipitation temperatures below $50-60{ }^{\circ} \mathrm{C}$ (i.e., earlystage formation during shallow burial), while dolomites with nonplanar boundaries (xenotopic crystals) form at temperatures superior to $50-60{ }^{\circ} \mathrm{C}$ (i.e., late precipitation during deeper burial). Furthermore, a cloudy-center-clear-rim texture is considered as typical for many sparry dolomites that form at lower temperatures (Warren, 2000) and multistage diagenetic events. The cloudy center often represents penecontemporaneous or (very) early post-depositional dolomite precipitation, while the clear rim forms by continuing growth during later diagenesis (Machel, 2004). Alternatively, the clear rim could also be interpreted as a low-temperature, early-burial syntaxial overgrowth cement (Choquette and Hiatt, 2008).

Yet, isotopic signatures of analyzed lagoonal and peritidal limestones (Fig. 9) are not in agreement with late diagenetic overprint (very low $\delta^{18} \mathrm{O}$ ). Oxygen isotope values of dolomites are mostly less negative than about $-2.5 \%$, a value classified as typical for lowtemperature, i.e., shallow-burial dolomites (Allan and Wiggins, 1993) but differ from the more negative values typical for a later diagenetic stage (Yoo and Lee, 1998; Reinhold, 1998). This is in accordance with a suggested maximum burial depth of $1000 \mathrm{~m}$ for the southern Jura Mountains (Trümpy, 1980). In summary, both petrographic and geochemical evidence points to an early diagenetic origin of dolomites.

\subsection{De-dolomitization - models and evidence}

Having postulated and discussed the likely mechanisms of dolomite formation, the focus must now be on dedolomitization. First, type Type- 1 dedolomites are discussed. Type- 1 dedolomites resemble the "hollow dolomites" of Swart et al. (2005), Jones (2007), or Nader et al. (2008). Apparently, the solution of dolomite started from the inside of (zoned?) dolomite crystals. In terms of their texture and crystal size and shape, type- 1 dedolomites shear clear similarities with type-1 dolomites. Dolomites frequently possess cores that are characterized by a high Ca content (high-Ca dolomites, HCD). During diagenesis, the high Ca content, a concentration of growth defects, and possibly the presence of highly soluble inclusions may promote selective dissolution of the HCD cores, creating "hollow dolomites" (Jones, 2007). According to Nordeng and Sibley (2003), dolomite formation in marine pore fluids is characterized by a rather long induction period. Metastable precursor minerals (e.g. the HCD of Jones, 2007; or ferroan dolomite, Purser et al., 1994a,b) are developed, which may progress into more stable dolomite or undergo dissolution if a change in pore-water chemistry occurs. The geometric distribution of type- 1 dedolomites in relatively small patches, however, does not support a dedolomitization process that was driven by the massive influx of (e.g., meteoric) fluids. In conclusion, the origin and diagenetic history of type- 1 dedolomites is not well understood. Localized process in the (shallow) burial domain seem likely but any interpretation of these features must remain on the level of a working hypothesis.

Type- 2 dolomites are probably better understood. The $\delta^{18} \mathrm{O}$ ratios of type-2 dedolomites are strongly depleted and plot in a similar range as those of limestones that were subject to meteoric vadose diagenesis (Videtich and Matthews, 1980; Allan and Matthews, 1982). Together, they form a vertical trend in the $\delta^{18} \mathrm{O} / \delta^{13} \mathrm{C}$-diagram (Fig. 9). This trend, referred to as the "meteoric calcite line" (Lohmann, 1988), encompasses the majority of variations present in a single meteoric water system. Consequently, it is proposed that the low $\delta^{18} \mathrm{O}$ values in both, vadose limestones and type- 2 dedolomites are probably due to interaction and chemical resetting with ${ }^{18} \mathrm{O}$-depleted meteoric waters. The significant differences in $\delta^{13} \mathrm{C}$ values are interpreted to result from differential exposure and variable effects of isotopically light soil-zone $\mathrm{CO}_{2}$ (Immenhauser et al., 2000, 2002). Compared to vadose limestones, type-2 dedolomites clearly define the most depleted part of the meteoric calcite line (Fig. 9). This suggests that limestones from the vadose zone were flushed by rainwater depleted in ${ }^{18} \mathrm{O}$ during short-termed exposure events. Type-2 dedolomitization, in contrast, is apparently related to more extended periods of subaerial exposure that allowed for the development of a thicker and more mature regolith and an enhanced effect of isotopically light soil $\mathrm{CO}_{2}$ resulting in low $\delta^{13} \mathrm{C}$ and $\delta^{18} \mathrm{O}$ ratios of type-2 dedolomites. In the case study presented here, an average meteoric calcite line of $\delta^{18} \mathrm{O}=-5.3 \%$ o was calculated (Lohmann, 1988) from all meteorically altered samples (mean value of all vadose limestones and type-2 dedolomites). This value is comparable to that reported by Nader et al. (2008) for dedolomites from the Jurassic of Lebanon.

The relation between stratigraphic position and type-2 dedolomite isotope signature is illustrated in Fig. 4c. Here, a relatively thin dolomite cap is terminated by a bed of type- 2 dedolomite accompanied by a significant shift to lower values both in $\delta^{18} \mathrm{O}$ and $\delta^{13} \mathrm{C}$. The trend of isotope ratios follows small-scale and medium-scale sequence architecture: the maxima in $\delta^{18} \mathrm{O}$ are found in multicoloured breccias (reworked lag deposits on supratidal flats) that represent the early transgressive deposits of small-scale sequence 20 . The isotopic signature of the type-2 dedolomites underlying a medium- and largescale ("third order") sequence boundary (Fig. 4c; section meter 74; Rameil, 2005), implies diagenetic alteration by meteoric water (low $\delta^{18} \mathrm{O}$ ) and the influence of soil zone $\mathrm{CO}_{2}$. As commonly found in such sections, paleosols have been removed by erosion during transgressive pulses. An exception is found in the Dôle section (Fig. 1). Here, recrystallized laminated crusts of type- 2 dedolomite (Fig. 5c, d) are clearly associated with $\mathrm{cm}$-thin clay-seams of red-brown colour that are interpreted as incipient soils (Rameil, 2005).

Where breccias occur within, or overlie type-2 dedolomites, they are interpreted as collapse breccias generated by the dissolution of uppermost Tithonian to Lower Cretaceous evaporite deposits (cf. Scholle et al., 1992, 1993). Upper Kimmeridgian and Lower to Middle Tithonian carbonate rocks in the study area are characterized by the presence of dolomites generated by penesaline fluids (as discussed earlier), and rare, thin layers of type-2 dedolomites as shown in Fig. 4c. Changes in platform geometry and palaeoclimatic conditions allowed for the development of massive evaporites during the Late Tithonian and Early Berriasian (Rameil, 2005). Meteoric dissolution of these evaporites may have produced the observed collapse breccias. Dissolution of gypsum and anhydrite led to fluids being overcharged with $\mathrm{Ca}^{2+}$ and rare in $\mathrm{Mg}^{2+}$ ions, resulting in the dissolution of dolomite and precipitation of calcite in the flow path of percolating fluids (Plummer et al., 1990; Bischoff et al., 1994).

\subsection{Relation of dolomitization to orbitally controlled sea-level change}

High-frequency sequences in Kimmeridgian to Berriasian carbonates of the Jura platform probably originated from orbitally forced sea-level changes (Colombié and Strasser, 2005; Rameil, 2005; Colombié and Rameil, 2007; Strasser, 2007). Medium-scale and small-scale sequences would thus represent the long and the short eccentricity cycle of Earth's orbit (400 ka and $100 \mathrm{ka}$ ) respectively. Assuming that this interpretation holds true, the timing of early diagenetic processes that are controlled by sea-level changes can be assessed within certain limitations. This is obviously the case for reflux dolomites and tidal-flat dolomites (type- 1 and type-2) that cap small-scale and medium-scale sequences. Consequently, thin dolomite caps that comprise only the regressive part of a single small-scale sequence (e.g., Fig. 4c) might imply active dolomitization intervals of less than $100 \mathrm{ka}$. As the time window during which deposition takes place within a sea-level cycle is usually significantly shorter than the sea-level cycle itself (Strasser et al., 1999), the phase of active 
dolomitization in a small-scale sequence probably lasts only thousands to a few tens of thousands of years. Thick intervals of type- 1 and type-2 dolomite capping medium-scale sequences can extend over several small-scale sequences (e.g., Fig. 4a, b). They thus represent longer and/or repeated phases of active reflux spanning over tens to hundreds of thousands years. The presented estimates on the duration of active dolomitization are comparable to durations as derived from mass-balance calculations (Montañez and Read, 1992). The superposition of different frequencies of sea-level change may have caused repeated reflux through the same sediment volume. This is a potential mechanism for the development of zoned type- 1 dolomite rhombs (Machel, 2004). Continuing brine flow after the "active" recharge mechanisms shut down ("latent reflux"; Jones et al., 2002) may have subsequently occurred for relatively extended periods.

The duration of exposure stages leading to the development of type-2 dedolomites is difficult to assess but it is proposed that type-2 dedolomitization in the Jura Mountains represents (at least partly) an early diagenetic modification, related to emersion events shortly after deposition. An argument in favour of an early dedolomitization is the stratiform geometry of all observed type-2 dedolomite bodies and their stratigraphic position underneath correlatable surfaces with evidence for relative sea-level fall. Consequently, the dm to several mthick stratiform bodies of dedolomite may actually represent the thin vadose zone that developed during $\mathrm{m}$-scale sea-level drops during Late Jurassic greenhouse time (Husinec and Read, 2007; see discussion in Rameil, 2005) but this is of course a hypothesis only. A detailed correlation of platform sections suggests that the sedimentary record is complete on the level of small-scale sequences in most places (Rameil, 2005). Consequently, the exposure time to meteoric fluids that created relatively thin, single-bed occurrences of type-2 dedolomites (e.g., Fig. 4c) was probably shorter than the duration of a smallscale sequence (less than $100 \mathrm{ka}$ ).

The timing and mechanisms of evaporite dissolution that contributed to the generation of thicker type-2 dedolomite bodies overlain by collapse breccias are poorly understood. Commonly, evaporite dissolution is a multistage process (Pomoni-Papaioannou and Karakitsios, 2002). Intrastratal collapse breccias in Permian sedimentary rocks, related to Tertiary telogenetic near-surface dissolution of evaporites, are described by Scholle et al. (1992,1993). In an analogous manner, a possible generation of the type- 2 dedolomites in the study area either shortly after deposition or late diagenetic, i.e., during the Tertiary uplift of the Jura Mountains, is conceivable.

\section{Conclusions}

Kimmeridgian to Berriasian sections in the Swiss and French Jura Mountains recorded three different types of early diagenetic dolomite and two types of dedolomite. The three types of dolomite can be distinguished by crystal geometry and size, stable isotope signature and the geometry of dolomite geobodies. Each type is interpreted to result from another dolomitizing mechanism: seepage reflux (type 1); the formation of laminated dolomitic crusts near the surface of tidal flats under a hot and (at least temporarily) arid climate by tidal/ evaporative pumping (type 2); and the selective dolomitization of burrows, probably related to microbial mediation (type 3 ). Isotope data point to sea water with normal marine or slightly enhanced salinities as a probable dolomitization fluid for all three types.

All three types of dolomite may co-exist within one bed. This implies that early dolomitization on shallow-water carbonate platforms is not necessarily caused by a single process but that different dolomite-forming processes may be active in parallel, penecontemporaneously, or alternatingly. The upper, regressive parts of highfrequency sequences frequently show massive type- 1 dolomitization with type- 2 intercalations ("dolomite caps"). The occurrence of type- 3 dolomite, in contrast, is independent of stratigraphic position but only correlates to mud-supported sediment texture. Using cyclostrati- graphic analysis, the time required for generating a dolomite cap is estimated to vary between several thousands of years to a few hundred thousands of years, depending on the dolomite cap's thickness and complexity. Locally, horizons of early cementation acted as flow barriers with respect to the percolating dolomitizing fluid, preventing deeper infiltration and thus creating a sharp lower boundary of the reflux-dolomite body that is not typical for dolomite bodies of reflux origin.

Type-2 dedolomitization took place during longer-term emersion events (e.g., large-scale/“3rd-order" sequence boundaries). The isotopic signature of type-2 dedolomites implies an important role of meteoric waters in their generation and the development of soil cover. The generation of several meter thick lenses of type-2 dedolomite underlying collapse breccias is probably related to the dissolution of evaporites. The timing and duration of the generation of type-2 dedolomites is not evident. Small volumes that underlie sequence boundaries may have formed during relatively short-termed $(<100 \mathrm{ka})$ emersions. Type-2 dedolomitization related to the dissolution of massive evaporites, however, is imagined as a multistage process, potentially extending over millions of years.

The development of conceptual models on dolomitization and dedolomitization patterns and their underlying mechanisms for the Jura platform is an important step towards an improved understanding of the interaction between sedimentary environments, highfrequency sea-level oscillations and early diagenetic processes. On the one hand, the study presented here can be used as a template for early diagenesis of cyclic carbonate successions in Mesozoic greenhouse settings. On the other hand, selected results, such as estimates on the timing of diagenetic processes and the possibility of early cementation affecting vertical fluid flow, might provide new input for integrated diagenetic modelling.

\section{Acknowledgements}

The author gratefully acknowledges the guidance of, and numerous discussions on the subject with, André Strasser (University of Fribourg). Discussions with Murray K. Gingras (University of Alberta) and Fiona Whitaker (University of Bristol) lead to plausible explanations for the genesis of the observed dolomitization patterns. Sébastien Bruchez (University of Lausanne) carried out the stable isotope analyses. Adrian Immenhauser (Ruhr-University Bochum) is thanked for invaluable help in improving earlier text versions. The comments of two anonymous reviewers and Brian Jones as associate editor further contributed to the development of the original manuscript. The presented research was financed by the Swiss National Science Foundation (projects no. 20-56491.99 and 20-67736.02) and the University of Fribourg.

\section{References}

Adams, J.E., Rhodes, M.L., 1960. Dolomitization by seepage refluxion. Bull. amer. Assoc. Petroleum Geol. 44, 1912-1920.

Allan, J.R., Matthews, R.K., 1982. Isotope signatures associated with early meteoric diagenesis. Sedimentology 29, 797-817.

Allan, J.R., Wiggins, W.D., 1993. Dolomite reservoirs - geochemical techniques for evaluating origin and distribution. AAPG Cont. Edu. Course Notes Ser. 36129 pp.

Baltzer, F., Kenig, F., Boichard, R., Plaziat, J.-C., Purser, B.H., 1994. Organic matter distribution, water circulation and dolomitization beneath the Abu Dhabi Sabkha (United Arab Emirates). In: Purser, B., Tucker, M., Zenger, D. (Eds.), Dolomites - A volume in honour of Dolomieu. Spec. Publs Int. Ass. Sediment., 21, pp. 409-427.

Banner, J.L., Hanson, G.N., Meyers, W.J., 1988. Determination of initial Sr isotopic compositions of dolostones from the Burlington-Keokuk Formation (Mississippian) constraints from cathodoluminescence, glauconite paragenesis, and analytical methods. J. Sediment. Petrol. 58, 673-687.

Bartolini, A., Baumgartner, P.O., Hunziker, J., 1996. Middle and Late Jurassic carbon stable-isotope stratigraphy and radiolarite sedimentation of the Umbria-Marche Basin (Central Italy). Eclogae geol. Helv. 89, 811-844.

Bischoff, J.L., Juliá, R., Shanks, W.C., Rosenbauer, R.J., 1994. Karstification without carbonic acid: bedrock dissolution by gypsum-driven dissolution. Geology 22, 995-998. 
Borkhataria, R., Aigner, T., Pipping, K.J.C.P., 2006. An unusual, muddy, epeiric carbonate reservoir: the Lower Muschelkalk (Middle Triassic) of the Netherlands. AAPG Bull. $90,61-89$.

Bosence, D.W.J., Wood, J.L., Rose, E.P.F., Qing, H., 2000. Low- and high-frequency sealevel changes control peritidal carbonate cycles, facies and dolomitization in the Rock of Gibraltar (Early Jurassic, Iberian Peninsula). J. geol. Soc. London 157, 61-74.

Budd, D.A., 1997. Cenozoic dolomites of carbonate islands: their attributes and origin. Earth Sci. Rev. 42, 1-47.

Cantrell, D.L., Al-Khammash, A., Jenden, P.D., 2007. Characterization and significance of dedolomite in Wadi Nisah, central Saudi Arabia. GeoArabia 12 (3), 15-30.

Carballo, J.D., Land, L.S., Miser, D.E., 1987. Holocene dolomitization of supratidal sediments by active tidal pumping, Sugarloaf Key, Florida. J. Sediment. Petrol. 57, 153-165.

Choquette, P.W., Hiatt, E.E., 2008. Shallow-burial dolomite cement: a major component of many ancient sucrosic dolomites. Sedimentology 55, 423-460.

Colombié, C., Strasser, A., 2005. Facies, cycles, and controls on the evolution of a keep-up carbonate platform (Kimmeridgian, Swiss Jura). Sedimentology 52, 1207-1227.

Colombié, C., Rameil, N., 2007. Tethyan-to-boreal correlation in the Kimmeridgian using high-resolution sequence stratigraphy (Vocontian Basin, Swiss Jura, Boulonnais, Dorset). Int. J. Earth Sci. (Geol. Rundschau) 96, 567-591.

Dehler, C.M., Elrick, M., Karlstrom, K.E., Smith, G.A., Crossey, LJ., Timmons, J.M., 2001 Neoproterozoic Chuar Group ( $800-742 \mathrm{Ma})$, Grand Canyon: a record of cyclic marine deposition during global cooling and supercontinent rifting. Sed. Geol. 141-142, 465-499.

Détraz, H., Mojon, P.-O., 1989. Evolution paléogéographique de la marge jurassienne de la Téthys du Tithonique-Portlandien au Valanginien: corrélations biostratigraphique et séquentielle des faciès marins à continentaux. Eclogae geol. Helv. 82, 37-112.

Fouke, B.W., Schlager, W., Vandamme, M.G.M., Henderiks, J., Van Hilten, B., 2005. Basinto-platform chemostratigraphy and diagenesis of the Early Cretaceous Vercors carbonate platform, SE France. Sed. Geol. 175, 297-314.

Gingras, M.K., Pemberton, S.G., Muelenbachs, K., Machel, H.G., 2004. Conceptual models for burrow-related, selective dolomitization with textural and isotopic evidence from the Tyndall Limestone, Canada. Geobiology 2, 21-30.

Goldhammer, R.K., Dunn, P.A., Hardie, L.A., 1990. Depositional cycles, composite sea-level changes, cycle stacking patterns, and the hierarchy of stratigraphic forcing: examples from Alpine Triassic platform carbonates. Geol. Soc. Am. Bull. 102, 535-562.

Horbury, A.D., Qing, H., 2004. 'Pseudobreccias' revealed as calcrete mottling and bioturbation in the Late Dinantian of the southern Lake District, UK. Sedimentology $51,19-38$.

Husinec, A., Read, J.F., 2007. The Late Jurassic Tithonian, a greenhouse phase in the Middle Jurassic-Early Cretaceous 'cool' mode: evidence from the cyclic Adriatic Platform, Croatia. Sedimentology 54, 317-337.

Immenhauser, A., Creusen, A., Esteban, M., Vonhof, H.B., 2000. Recognition and interpretation of polygenic discontinuity surfaces in the Middle Cretaceous Shuaiba, Nahr Umr, and Natih Formations of northern Oman. GeoArabia, 5, 299-322.

Immenhauser, A., Kenter, J.A.M., Ganssen, G., Bahamonde, J.R., van Vliet, A., Saher, M.H., 2002. Origin and significance of isotope shifts in Pennsylvanian carbonates (Asturias, NW Spain). J. Sediment. Res. 72, 82-94.

Joachimski, M.M., 1994. Subaerial exposure and deposition of shallowing upward sequences: evidence from stable isotopes of Purbeckian peritidal carbonates (basal Cretaceous), Swiss and French Jura Mountains. Sedimentology 41, 805-824.

Jones, B., 2007. Inside-out dolomite. J. Sed. Res. 77, 539-551.

Jones, G., Whitaker, F.F., Smart, P.L., Sanford, W.E., 2002. Fate of reflux brines in carbonate platforms. Geology 30, 371-374.

Kaufman, J., 1994. Numerical models of fluid flow in carbonate platforms: implications for dolomitization. J. Sed. Res. A64, 128-139.

Land, L.S., 1980. The isotopic and trace element geochemistry of dolomite: the state of the art. In: Zenger, D.H., Dunham, J.B., Ethington, R.L. (Eds.), Concepts and models of dolomitization. SEPM Spec. Publ., 28, pp. 87-110.

Lippmann, F., 1973. Sedimentary Carbonate Minerals. Springer, Berlin.

Lohmann, K.C., 1988. Geochemical patterns of meteoric diagenetic systems and their application to studies of paleokarst. In: James, N.P., Philip, W.C. (Eds.), Paleokarst. Springer, Berlin, pp. 58-80.

Machel, H.G., 2002. The dolomite problem - quo vadis? In: Hüssner, H., Hinderer, M., Götz, A.E., Petschick, R. (Eds.), SEDIMENT 2002, 17. Sedimentologentreffen, Frankfurt a.M./Darmstadt, 29.-31. Mai 2002, Kurzfassungen und Programm. Schr. Deutsch. Geol. Ges., 17, pp. 135-140.

Machel, H.G., 2004. Concepts and models of dolomitization: a critical reappraisal. In: Braithwaite, C.J.R., Rizzi, G., Darke, G. (Eds.), The geometry and petrogenesis of dolomite hydrocarbon reservoirs. Geol. Soc. London Spec. Publ., 235, pp. 7-63.

Mazullo, S.J., Bischoff, W.D. Teal, C.S., 1995. Holocene shallow subtidal dolomitization by near-normal seawater, northern Belize. Geology 23, 431-344.

McKenzie, J.A., 1981. Holocene dolomitization of calcium carbonate sediments from the coastal sabkhas of Abu Dhabi, U.A.E.: a stable isotope study. J. Geol. 89, 185-198.

Melim, L.A., Scholle, P.A., 2002. Dolomitization of the Capitan Formation forereef facies (Permian, west Texas and New Mexico): seepage reflux revisited. Sedimentology $49,1207-1227$.

Meyer, M., 2000. Le complexe récifal kimméridgien-tithonien du Jura méridional interne (France), évolution multifactorielle, stratigraphie et tectonique. Terre Environ. 24 179 pp.

Mirsal, I.A., Zankl, H., 1985. Some phenomenological aspects of carbonate geochemistry: the control effect of transition metals. Geol. Rundsch. 74, 367-377.

Montañez, I.P., Read, J.F., 1992. Eustatic control on early dolomitization of cyclic peritidal carbonates: evidence from the Early Ordovician Upper Knox Group, Appalachians. Geol. Soc. Amer. Bull. 104, 872-886.
Mutti, M., Simo, J.A., 1994. Distribution, petrography and geochemistry of early dolomite in cyclic shelf facies, Yates Formation (Guadalupian), Capitan Reef Complex, USA. Spec. Publs Int. Ass. Sediment. 21, 91-107.

Nader, F.H., Swennen, R., Keppens, E., 2008. Calcitization/dedolomitization of Jurassic dolostones (Lebanon): results from petrographic and sequential geochemical analyses. Sedimentology 55, 1467-1485.

Newell, N.D., Rigby, J.K., Fischer, A.G., Whiteman, A.J., Hilcox, J.E., Bradley, J.S., 1953. The Permian reef complex of the Guadalupe Mountains region, Texas and New Mexico. W.H. Freeman, New York. 236 pp.

Nordeng, S.H., Sibley, D., 2003. The induction period and dolomite kinetics in experimental and natural systems. 12th Bathurst Meeting - Int. Conference of Carbonate Sedimentologists. 8th-10th July 2003 Durham - Programme and Abstracts, p. 74.

Padden, M., Weissert, H., Funk, H., Schneider, S., Gansner, C., 2002. Late Jurassic lithologica evolution and carbon-isotope stratigraphy of the western Tethys. Eclogae geol. Helv. 95, 333-346.

Plummer, N.J., Busby, R.L., Handshaw, B., 1990. Geochemical modeling of the Madison Aquifer in parts of Montana, Wyoming, and South Dakota. Water Resour. Res. 26, 1981-2014.

Plunkett, J.M., 1997. Early diagenesis of shallow platform carbonates in the Oxfordian of the Swiss Jura Mountains. PhD Thesis no. 1158, University of Fribourg, 168 pp.

Pomoni-Papaioannou, F., Karakitsios, V., 2002. Facies analysis of the Trypali carbonate unit (Upper Triassic) in central-western Crete (Greece): an evaporite formation transformed into solution-collapse breccias. Sedimentology 49, 1113-1132.

Purser, B.H., 1975. Tidal sediments and their evolution in the Bathonian carbonates of Burgundy, France. In: Ginsburg, R.N. (Ed.), Tidal deposits: a casebook of recent examples and fossil counterparts. Springer, Berlin, pp. 335-343.

Purser, B.H., Brown, A., Aissaoui, D.M., 1994a. Nature, origins and evolution of porosity in dolomites. In: Purser, B., Tucker, M., Zenger, D. (Eds.), Dolomites - A volume in honour of Dolomieu. Spec. Publs Int. Ass. Sediment, 21, pp. 283-308.

Purser, B.H., Tucker, M.E., Zenger, D.H., 1994b. Problems, progress and future research concerning dolomites and dolomitization. In: Purser, B., Tucker, M., Zenger, D. (Eds.), Dolomites - A volume in honour of Dolomieu. Spec. Publs Int. Ass. Sediment., 21, pp. 3-20.

Qing, H., Bosence, D.W.J., Rose, E.P.F., 2001. Dolomitization by penesaline sea water in Early Jurassic peritidal platform carbonates, Gibraltar, western Mediterranean. Sedimentology 48, 153-163.

Rameil, N., 2005. Carbonate sedimentology, sequence stratigraphy, and cyclostratigraphy of the Tithonian in the Swiss and French Jura Mountains: a high-resolution record of changes in sea level and climate. GeoFocus 13, 246 pp.

Rasser, M.W., Fenninger, A., 2002. Paleoenvironmental and diagenetic implications of $\delta^{18} \mathrm{O}$ and $\delta^{13} \mathrm{C}$ isotope ratios from the Upper Jurassic Plassen limestone (Northern Calcareous Alps, Austria). Géobios 35, 41-49.

Reinhold, C., 1998. Multiple episodes of dolomitization and dolomite recrystallization during shallow burial in Upper Jurassic shelf carbonates: eastern Swabian Alb southern Germany. Sed. Geol. 121, 71-95.

Schlager, W., 2005. Carbonate Sedimentology and Sequence Stratigraphy. SEPM Concepts in Sedimentology and Paleontology 8. SEPM, Tulsa, Oklahoma. 200 pp.

Scholle, P.A., Ulmer, D.S., Melim, L.A., 1992. Late-stage calcites in the Permian Capitan Formation and its equivalents, Delaware Basin margin, west Texas and New Mexico: evidence for replacement of precursor evaporites. Sedimentology 39, 207-234.

Scholle, P.A., Stemmerik, L., Ulmer-Scholle, D., Di Liegro, G., Henk, F.H., 1993. Palaeokarstinfluenced depositional and diagenetic patterns in Upper Permian carbonates and evaporites, Karstryggen area, central East Greenland. Sedimentology 40, 895-918.

Sheppard, S.M.F., Schwarz, H.P., 1970. Fractionation of carbon and oxygen isotopes and magnesium between metamorphic calcite and dolomite. Contrib. Mineral. Petrol. 26, 161-198.

Shinn, E.U., Ginsburg, R.N., Lloyd, R.M., 1965. Recent supratidal dolomite from Andros Island, Bahamas. Dolomitization and Limestone Diagenesis 13, 112-123.

Sibley, D.F., Gregg, J.M., 1987. Classification of dolomite rock textures. J. Sed. Petr. 57, 967-975.

Simms, M.A., 1984. Dolomitization by groundwater-flow systems in carbonate platforms. Trans. Gulf Coast Assoc. Geol. Soc. 34, 411-420.

Sommaruga, A., 1997. Geology of the central Jura and the molasse basin: new insight into an evaporate-based foreland fold and thrust belt. Mém. Soc. Neuch. Sci. nat. 12, $1-176$.

Strasser, A., 1988. Shallowing-upward sequences in Purbeckian peritidal carbonates (lowermost Cretaceous, Swiss and French Jura, Switzerland). Sedimentology 35, 369-383.

Strasser, A., 2007. Astronomical time scale for the Middle Oxfordian to Late Kimmeridgian in the Swiss and French Jura Mountains. Swiss Journal of Geoscience 100, 407-429.

Strasser, A., Pittet, B., Hillgärtner, H., Pasquier, J.-B., 1999. Depositional sequences in shallow carbonate-dominated sedimentary systems: concepts for a high-resolution analysis. Sed. Geol. 128, 201-221.

Sun, S.Q., 1994. A reappraisal of dolomite abundance and occurrence in the Phanerozoic J. Sed. Res. A64, 396-404.

Swart, P.K., Cantrell, D.L., Westphal, H., Handford, C.R., Kendall, C.G., 2005. Origin of dolomite in the Arab-D reservoir from the Ghawar Field, Saudi Arabia: evidence from petrographic and geochemical constraints. J. Sed. Res. 75, 476-491.

Thierry, J., 2000. Early Tithonian. In: Dercourt, J., Gaetani, M., Vrielynck, B., Barrier, E., Biju-Duval, B., Brunet, M.F., Cadet, J.P., Crasquin, S., Sandulescu, M. (Eds.), Atlas PeriTethys: palaegeographical maps. Paris.

Trümpy, R., 1980. Geology of Switzerland - A Guidebook. Part A: An Outline of the Geology of Switzerland, Basel.

van Lith, Y., Warthmann, R., Vasconcelos, C., McKenzie, J.A., 2003a. Sulphate-reducing bacteria induce low-temperature Ca-dolomite and high Mg-calcite formation. Geobiology 1, 71-79. 
van Lith, Y., Warthmann, R., Vasconselos, C., McKenzie, J.A., 2003b. Microbial fossilization in carbonate sediments: a result of the bacterial surface involvement in dolomite precipitation. Sedimentology 50, 237-245.

Vasconcelos, C., McKenzie, J.A., 1997. Microbial mediation of modern dolomite precipitation and diagenesis under anoxic conditions (Lagoa Vermelha, Rio de Janeiro, Brazil). J. Sed. Res. 67, 379-390.

Videtich, P.E., Mattews, R.K., 1980. Origin of discontinuity surfaces in limestones: isotopic and petrographic data, Pleistocene of Barbados, West Indies. J. Sed. Petr. 50, 971-980.

Wanless, H.R., Tedesco, L.P., Tyrell, K.M., 1988. Production of subtidal tubular and surficial tempestites by hurricane Kate, Caicos platform, British West Indies. J. Sed. Petr. 58, 739-750

Warren, J., 2000. Dolomite: occurrence, evolution and economically important associations. Earth Sci. Rev. 52,1-81.
Whitaker, F.F., Smart, P.L., 1993. Circulation of saline ground water in carbonate platforms - a review and case study from the Bahamas. In: Horbury, A.D., Robinson, A.G. (Eds.), Diagenesis and basin development. AAPG Studies in Geology, 36, pp. $113-132$

Whitaker, F.F., Smart, P.L., Vahrenkamp, V.C., Nicholson, H., Wogelius, R.A., 1994. Dolomitization by near-normal seawater? Field evidence from the Bahamas. Int. Assoc. Sedimentol. Spec. Publ. 21, 111-132.

Yoo, C.M., Lee, Y.I., 1998. Origin and modification of early dolomites in cyclic shallow platform carbonates, Yeongheung Formation (middle Ordovician), Korea. Sed. Geol. 118, 141-157.

Ziegler, P.A., 1990. Geological Atlas of Western and Central Europe - 2nd and Completely Revised Edition. 239 pp., 56 enclosures. (Shell Intern. Petrol. Maatschappij B.V. / Geol. Soc.). 